\title{
In situ weathering of rocks or aeolian silt deposition: key parameters for verifying parent material and pedogenesis in the Opawskie Mountains-a case study from SW Poland
}

\author{
Aleksandra Loba ${ }^{1}$ (D) Marcin Sykuła ${ }^{2} \cdot$ Jakub Kierczak $^{3} \cdot$ Beata Łabaz $^{1} \cdot$ Adam Bogacz $^{1} \cdot$ Jarosław Waroszewski $^{1}$
}

Received: 14 November 2018 / Accepted: 5 June 2019 / Published online: 26 June 2019

(C) The Author(s) 2019

\begin{abstract}
Purpose The aims: (1) to investigate the role of the in situ weathering of bedrock in providing substrate for soil formation; (2) to evaluate the aeolian contribution to the mountainous soils in the vicinity of thick loess cover; and (3) to determine the influence of aeolian silt on further soil development.

Materials and methods The sampled sites were arranged along the slope toposequence, where an aeolian/silt admixture possibly occurred. Each soil catena started at the top of a hill and ended at its foot. Such an arrangement of the soil profiles ensured the tracking of loess thickness variations and detection of the depth of the residuum-derived materials. One reference soil profile, consisting of aeolian silt deposits, was made. The following soil properties were determined: $\mathrm{pH}$, organic carbon content, soil texture, exchangeable acidity, exchangeable ions and geochemistry. In addition, thin sections were prepared from rock samples to confirm the type of bedrock present.

Results and discussion The soils in the studied area were classified as Cambisols, Luvisols and Stagnosols, characterised by silt loam texture and a high content of elements indicating an aeolian silt contribution- $\mathrm{Hf}$ ( 7.4 to $14.8 \mathrm{ppm}$ ) and $\mathrm{Zr}$ (274.4 to $549.0 \mathrm{ppm}$ ). These values differ strongly from the residues typical of weathered quartzite, greywacke or catalasite substrates, which generally have low concentrations of $\mathrm{Hf}$ and $\mathrm{Zr}$ ( 0.7 to $7.0 \mathrm{ppm}$ and 26.0 to $263 \mathrm{ppm}$, respectively). Based on the morphological, textural and geochemical data of the studied soils, three layers were distinguished, which show different inputs of aeolian silt: (1) an aeolian silt mantle; (2) a mixed zone in which loess was incorporated into the local material; and (3) a basal zone, free of the influence of aeolian silt. Based on the obtained results, a hypothetical pathway for soil formation in mountainous areas, influenced by aeolian silt admixing, was proposed.

Conclusions Our study demonstrates that the soils developed in the Opawskie Mountains are characterised by an aeolian silt influence. This differentiates them from weakly developed soils, which comprise materials formed during in situ weathering only. Materials originating from bedrock weathering did not play an independent role as the parent material for the studied pedons. Aeolian silt was admixed with already existing autochthonous substrates, or completely replaced them. This influence on the soil formation resulted in the occurrence of Luvisols, Stagnosols and Cambisols. Such soils cannot be formed from the weathering of quartzites and greywackes, which contribute to a less structure-forming medium.
\end{abstract}

Keywords Aeolian admixture $\cdot$ Geochemistry $\cdot$ In situ weathering $\cdot$ Loess-influenced soils $\cdot$ Soil formation $\cdot$ Stable elements

Responsible editor: Arnaud Temme

Aleksandra Loba aleksandra.loba@upwr.edu.pl

1 Wrocław University of Environmental and Life Sciences, Institute of Soil Science and Environmental Protection, Grunwaldzka 53, 50-357 Wrocław, Poland
2 Department of Soil Science and Landscape Management, Nicolaus Copernicus University in Toruń, Lwowska St. 1, 87-100 Toruń, Poland

3 Institute of Geological Sciences, University of Wrocław, Cybulskiego 30, 50-205 Wrocław, Poland 


\section{Introduction}

Parent material directly influences soil-forming processes (Jenny 1941; Dokuchaev 1967; Mason et al. 2016; RodrigoComino et al. 2018) because, via weathering, it slowly disintegrates, delivering a coarse or finer grained substrate for further alteration processes. The weathering of bedrock has long been considered to be the only, and most crucial, source of material for soil formation in mountainous environments (Romashkevich 1979; Wang et al. 1997; Hahm et al. 2014; Lin and Feng 2015; Kroyan 2017; Mazurek et al. 2018). However, in recent years, attention has been paid to the impact of aeolian silt on mountainous soils, and there is an awareness of the fact that aeolian silts have often been covered by/ involved in slope deposits (Kufmann 2003; Schaetzl and Luehmann 2013; Feng et al. 2014; Martignier et al. 2015; Pasquini et al. 2017; Gild et al. 2018; Waroszewski et al. 2018a, b, 2019). An aeolian silt contribution to a soil may occur during pedogenesis; therefore, it can enhance or weaken the soil-forming processes, or provide the initial parent material for soil formation. An aeolian silt admixture into a soil can appear in different forms. In some cases, loess/aeolian silt can be deposited as thick aeolian drapes (Gild et al. 2018) or mantles of variable thickness (Waroszewski et al. 2018a), and become mixed with autochthonous materials (Waroszewski et al. 2019) or occur as an aeolian 'contaminant agent', which would be hard to identify without using geochemical proxies (Yaalon and Ganor 1973; Muhs 2013; Kowalska et al. 2019; Waroszewski et al. 2019). Although the areas where aeolian silt has contributed to soil formation are widely distributed, the distinction of aeolian-derived materials is still problematic, and the process of pedogenesis supported by loess addition is not fully understood and has not been adequately described.

To date, whilst deep loess deposits have been examined in detail, from both the morphological and chronostratigraphical points of view (Jary 1999, 2007, 2009; Sprafke et al. 2014; Markovic et al. 2018), thin, pedoturbated loess deposits have still not been widely investigated and require more attention (Schaetzl et al. 2018). This knowledge gap exists especially at the edges of loess patches, where the distribution of aeolian silt, and the nature of its incorporation into other substrates (regoliths, saprolites, soils), is still unclear (Karathanasis and Macneal 1994). In some cases, thin, surficial loess mantles overlie coarser materials, and a coarser-textured mixed layer is often developed (Schaetzl and Luehmann 2013), which blurs the primary silt loam texture and, due to pedoturbation and mixing processes, results in a loam texture (Schaetzl and Luehmann 2013; Waroszewski et al. 2018a). This causes problems with the evaluation of the initial thickness of loess deposits, and/or the initial particle size distribution of the material upon which the loess was deposited (Schaetzl and Luehmann 2013). In other cases, the in situ bedrock (basal periglacial zone) is clearly separated from the allochthonous material, or is gradually separated by an intermediate layer/ mixed zone (Semmel and Terhorst 2010; Waroszewski et al. 2018a) that transfers into the loess mantle.

To verify the presence of aeolian silt in soils and its impact on their formation, several approaches have been proposed, including Kufmann (2003) in her research on the Northern Calcareous Alps, and Gild et al. (2018), who used mineralogical (X-ray diffraction, heavy minerals) and pedological (grain size, soil chemistry) data to determine the origin of the materials from which the soil was formed (in situ weathering or aeolian silt). However, Waroszewski et al. (2019) proposed morphological, textural, mineralogical and geochemical proxies to investigate the scale of the inheritance of the signatures typical of loess-derived and in situ-derived substrates in soils that have both components present as parent material due to past periglacial processes (slope and loess deposition).

Therefore, in this study, we attempted to use grain size composition and geochemical proxies to confirm a hypothesis: the in situ weathering of local rocks is not the only source of material for soil development in the territory of the Opawskie Mountains (SW Poland), where the whole region is covered by a large loess body (Głubczyce Upland). Whilst in a previous study of this area, only a local origin for the soil substrates was considered (Szlachta 2006), and we propose a wider view of the admixture of the allochthonous material, such as aeolian silt. Thus, the aims of this study were as follows: (1) to investigate the role of the in situ weathering of the bedrock in providing substrate for soil formation; (2) to evaluate aeolian contributions to the mountainous soils in the vicinity of thick loess covers; and (3) to determine the influence of aeolian silt on further soil development.

\section{Study area}

The research was carried out in the Opawskie Mountains, located in SW Poland (Fig. 1). Most of this area is under the protection of the Opawskie Mountains Landscape Park. The geology of the Opawskie Mountains is very varied, comprising two primary geological units - metamorphics in the west and the Silesian-Moravian flysch in the east (Sitko 1994). The rocks that occur in the range are of Devonian and Carboniferous age, covered by much younger Quaternary sediments (Oberc 1972). The rocks are older in the west, becoming younger to the east (Oberc 1972). In the western Opawskie Mountains, greywackes and glacial tills occur (Sawicki 1995).

In the close vicinity of the Opawskie Mountains, deep loess deposits, hosting palaeosols (with well-established features on the Głubczyce Upland), have been recognised (Jary 1996; Badura et al. 2013). The stage of periglacial morphogenesis in this area is mainly related to the accumulation of loess; however, the highest parts of the slopes of the Glubczyce 


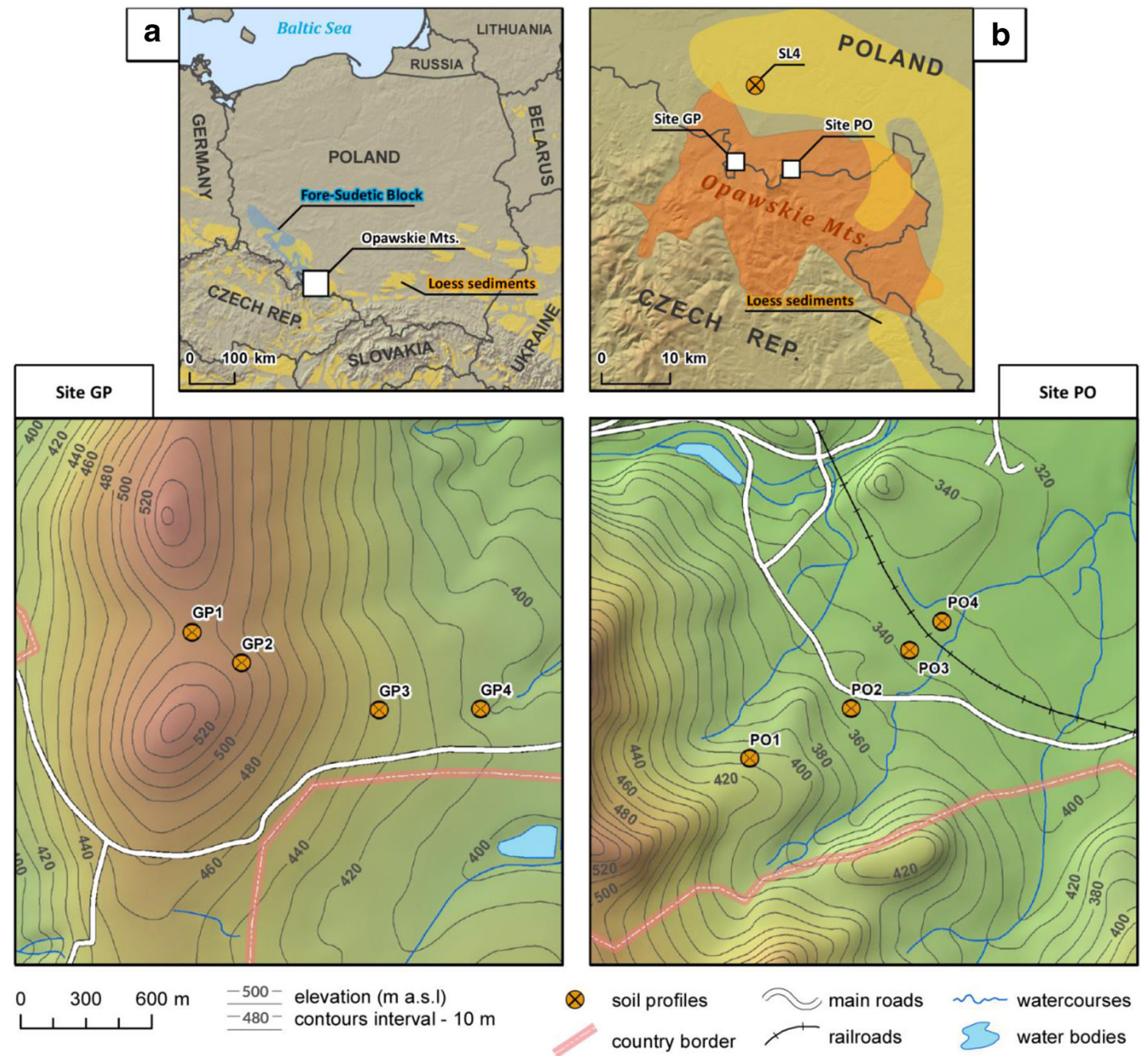

Fig. 1 Map showing study sites in the Opawskie Mts. (SW Poland) (A and B-loess distribution based on Haase et al. 2007, digital elevation model — SRTM-C 30“(A); SRTM-C 3" (B); Site GP and Site PO-topographic data and elevation model based on Vmap level 2)

Upland are not covered with aeolian silt (Jary 1996). Jary and Ciszek (2013) divided these deposits into four main Late Pleistocene loess-palaeosol sections: (1) S1-a palaeosol complex with a diagnostic Bt horizon that can be correlated to the Eemian and Early Weichselian; (2) L1L2 - a lower, younger loess unit that correlates to the Early Pleniweichselian, which covers the Eemian-Early Glacial pedocomplex. Its upper part is signalled by succeeding phases of pedogenesis; (3) L1S1 - a polygenetic soil linked to the Middle Pleniweichselian, and occurring mainly as a welldeveloped gley soil; and (4) L1L1 — an upper, younger loess unit correlated with the Late Pleniweichselian.

The native vegetation is represented by beech and mixed coniferous forests (Zygmańska 2016). According to the Köppen climate classification, the Opawskie Mountains experience a warm summer humid continental climate. The average annual temperature is $7{ }^{\circ} \mathrm{C}$, with average temperatures in the warmest and coldest months being $17.5^{\circ} \mathrm{C}$ (July) and $-2{ }^{\circ} \mathrm{C}$
(January), respectively (Bac and Rojek 2012). The annual average precipitation is $650 \mathrm{~mm}$. Snow cover in this part of the Sudetes occurs for 50-60 days per year (Bac and Rojek 2012).

\section{Materials and methods}

\subsection{Field sampling}

This study was based on two transects arranged along the slope catena (Figs. 1 and 2). The chosen slopes were characterised by different geological and topographic conditions. The first (GP) was located on the Parkowa Mountain (530 $\mathrm{m}$ a.s.1.), which is, according to geological mapping (Sawicki 1995), composed of the oldest (Early Devonian) metamorphic rocks in the region, comprising quartzites and schists. The second transect (PO) was situated in the vicinity of the village of Pokrzywna, where mainly Late Devonian 


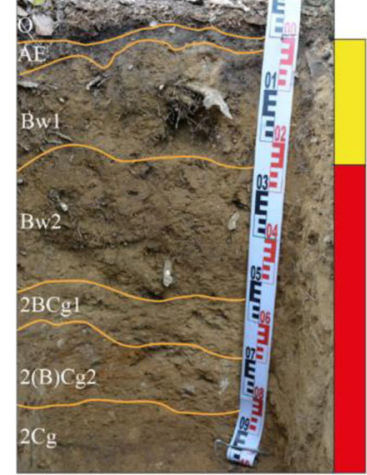

GP 1

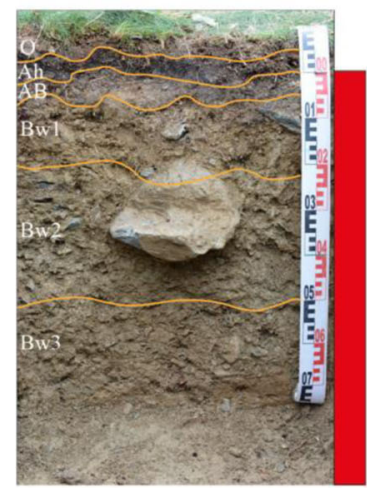

PO 1

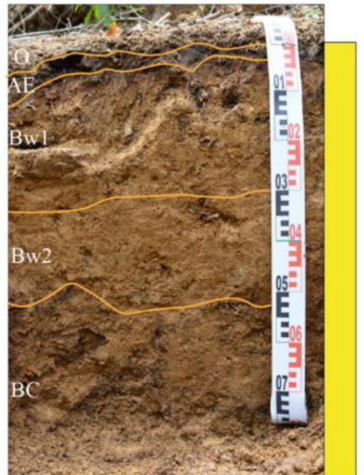

GP 2

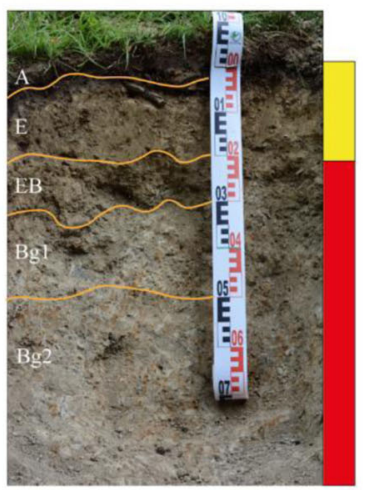

PO 2

$\square$ aeolian mantles

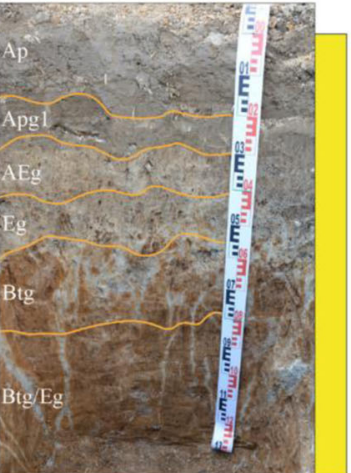

GP 3

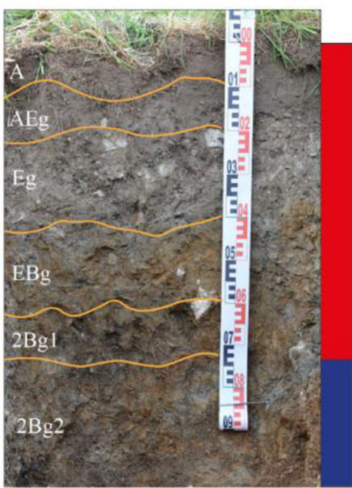

$\mathrm{PO} 3$

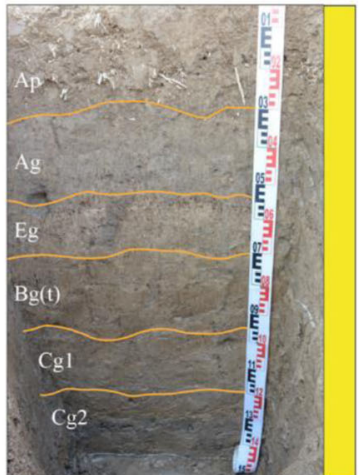

GP 4

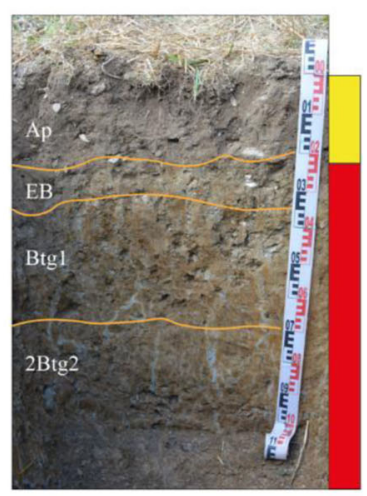

PO 4

Fig. 2 Studied soils with assigned layers depended on aeolian silt admixture

schists and greywackes occur (Miszewski 1977). The geological map (Sawicki 1995) does not reveal any thick or thin loess deposits on the studied slopes.

The sampling sites were arranged along the slope toposequence, where the possible aeolian silt admixture occurred with variable intensity. Each soil catena started at the top of the hill and ended at its foot. This arrangement of the soil profiles was to ensure the tracking of possible aeolian silt thickness variations and the detection of the depth of the presence of residuum-derived materials. Eight soil profiles (GP1GP4 and PO1-PO4; Fig. 1, Table 1) were described using the standard guidelines for soil description (FAO 2006), and the soil classification was established using the FAO-WRB system (IUSS Working Group WRB 2015). Moreover, a reference profile (SL4) comprising homogeneous aeolian silt was dug on a flat forefield under the dominance of thick loess deposits. Prior to analysis, all the samples were dried, crushed and passed through a 2-mm mesh sieve. In addition, fragments of local rocks that occurred in the soil profiles were taken for thin sectioning for empirical classification.

\subsection{Rock thin sections}

Thin sections were prepared from the rock samples taken from the soils, using standard polishing procedures.
Petrographic descriptions of the polished sections of the dominant rock types were carried out using a Leica DM2500P optical microscope in transmitted and reflected light. The modal composition of the studied rocks was estimated by point counting, using the freeware software JMicroVision v.1.2.7.

\subsection{Basic soil properties (soil texture, $\mathrm{pH}$, exchangeable acidity, exchangeable ions, soil organic carbon)}

The particle-size distribution was measured using a sieving (sand fraction) and hydrometer method to determine the silt and clay fractions (Van Reeuwijk 2002). The soil pH (in deionized water) was potentiometrically measured in a 1:2.5 suspension. The exchangeable acidity was extracted with $1 \mathrm{M} \mathrm{KCl}$ and titrated potentiometrically, whilst the exchangeable ions $\left(\mathrm{Ca}^{2+}, \mathrm{Mg}^{2+}, \mathrm{K}^{+}, \mathrm{Na}^{+}\right)$were extracted with $1 \mathrm{M} \mathrm{NH}_{4} \mathrm{CH}_{3} \mathrm{CO}_{2}$ (ammonium acetate) at $\mathrm{pH} 7$ (Van Reeuwijk 2002). The soil organic carbon (SOC) content was determined by dry combustion at $550{ }^{\circ} \mathrm{C}$ and the non-dispersive infrared absorption of $\mathrm{CO}_{2}$ using a Ströhlein CS-mat 5500 analyser (the soils studied were carbonate-free; thus, the total measurable carbon was organic carbon). 
Table 1 Main characteristics of studied sites

\begin{tabular}{|c|c|c|c|c|c|}
\hline Soil profile & Elevation (m asl) & Exposure & Latitude and longitude & Present land use & World Reference Base (IUSS 2015) \\
\hline GP1 & 504 & $\mathrm{NE}$ & $\begin{array}{l}50^{\circ} 17^{\prime} 17.861^{\prime \prime} \\
17^{\circ} 21^{\prime} 29.511^{\prime \prime}\end{array}$ & Forest & $\begin{array}{l}\text { Dystric Endoskeletic Cambisol } \\
\text { (Loamic, Siltic, Humic, Endodensic, Endorapic) }\end{array}$ \\
\hline GP2 & 500 & $\mathrm{NE}$ & $\begin{array}{l}50^{\circ} 17^{\prime} 13.408^{\prime \prime} \\
17^{\circ} 21^{\prime} 41.383^{\prime \prime}\end{array}$ & Forest & Dystic Folic Cambisol (Siltic, Colluvic) \\
\hline GP3 & 437 & $\mathrm{E}$ & $\begin{array}{l}50^{\circ} 17^{\prime} 6.925^{\prime \prime} \\
17^{\circ} 22^{\prime} 13.155^{\prime \prime}\end{array}$ & Arable land & Albic Stagnic Luvisol (Siltic, Aric, Cutanic, Densic, Ochric) \\
\hline GP4 & 404 & $\mathrm{E}$ & $\begin{array}{l}50^{\circ} 17^{\prime} 7.252^{\prime \prime} \\
17^{\circ} 22^{\prime} 36.58^{\prime \prime}\end{array}$ & Arable land & Eutric Stagnosol (Siltic, Aric, Colluvic, Drainic, Humic) \\
\hline PO1 & 410 & $\mathrm{E}$ & $\begin{array}{l}50^{\circ} 16^{\prime} 29.947^{\prime \prime} \\
17^{\circ} 28^{\prime} 18.779^{\prime \prime}\end{array}$ & Forest & Dystric Skeletic Folic Cambisol (Episiltic, Amphiloamic) \\
\hline $\mathrm{PO} 2$ & 356 & $\mathrm{E}$ & $\begin{array}{l}50^{\circ} 16^{\prime} 37.644^{\prime \prime} \\
17^{\circ} 28^{\prime} 41.965^{\prime \prime}\end{array}$ & Forest & Dystric Folic Cambisol (Siltic, Densic) \\
\hline PO3 & 340 & $\mathrm{E}$ & $\begin{array}{l}50^{\circ} 16^{\prime} 46.252^{\prime \prime} \\
17^{\circ} 28^{\prime} 55.39^{\prime \prime}\end{array}$ & Grassland & Eutric Stagnosol (Aric, Episiltic, Endoloamic, Endoskeletic) \\
\hline $\mathrm{PO} 4$ & 333 & $\mathrm{E}$ & $\begin{array}{l}50^{\circ} 16^{\prime} 50.849^{\prime \prime} \\
17^{\circ} 29^{\prime} 2.454^{\prime \prime}\end{array}$ & Arable land & Albic Stagnic Luvisol (Anosiltic, Aric, Cutanic) \\
\hline
\end{tabular}

\subsection{Geochemical analysis}

The geochemical composition of the soils was determined from selected representative horizons in each soil profile using inductively coupled plasma-atomic emission spectroscopy and mass spectrometry after $\mathrm{Li}_{2} \mathrm{~B}_{4} \mathrm{O}_{7}$ (lithium borate) fusion and further dissolution of the samples with $\mathrm{HNO}_{3}(\mathrm{ACME}$ Labs, Canada). The analytical reproducibility (2-sigma), as estimated from replicate analyses of six randomly chosen samples, ranged from $0\left(\mathrm{SiO}_{2}\right)$ to $10 \%\left(\mathrm{Cr}_{2} \mathrm{O}_{3}\right)$ at a $95 \%$ confidence level. The analytical accuracy (2-sigma), as estimated from nine measurements of the reference sample, SO-19, was from $0.9\left(\mathrm{Al}_{2} \mathrm{O}_{3}\right)$ to $8.3\left(\mathrm{NaO}_{2}\right)$ at a $95 \%$ confidence level. Further geochemical analyses based on immobile elements ( Zr, Hf, Th, V) with high ionic potentials, which are considered to be indicators of an aeolian silt contribution (Muhs and Benedict 2006; Ahmad and Chandra 2013; Scheib et al. 2014), were performed. In addition, calculations based on the major element $\left(\mathrm{Na}_{2} \mathrm{O}, \mathrm{Al}_{2} \mathrm{O}_{3}, \mathrm{~K}_{2} \mathrm{O}\right)$, concentrations of which are characteristic of aeolian materials (Ujvari et al. 2008), were produced. The ratios and bivariate plots of $\mathrm{Zr} /$ $\mathrm{Hf}, \mathrm{Zr} / \mathrm{V}$ vs. Th/V, and $\mathrm{Na}_{2} \mathrm{O} / \mathrm{Al}_{2} \mathrm{O}_{3}$ vs. $\mathrm{K}_{2} \mathrm{O} / \mathrm{Al}_{2} \mathrm{O}_{3}$ (Munroe et al. 2007; Ujvari et al. 2008; Ahmed and Chandra 2013) were derived in order to distinguish in situ quartzite and schist material from aeolian silt horizons.

\section{Results}

\subsection{Classification of the rock fragments occurring in the soils}

A rock fragment from profile GP2 was mostly composed of angular and anhedral grains of quartz, averaging about $0.25 \mathrm{~mm}$ across (Fig. 3a). Quartz made up over $90 \%$ vol. of the sample. Furthermore, irregular aggregates, composed of anhedral opaques, and subhedral flakes of biotite, chlorite and muscovite were present in the rock. Locally, opaques and muscovite were present as secondary fillings in fissures in the rock (Fig. 3b, c). Muscovite was also present in the rock as single subhedral flakes of up to $0.25 \mathrm{~mm}$ in diameter. These characteristics led to the conclusion that the rock was quartzite. A rock sample from profile $\mathrm{PO} 3$ consisted of angular grains of quartz and feldspars (alkali feldspar and plagioclase), averaging $0.25-0.5 \mathrm{~mm}$ across, occurring in a finer grained matrix composed of chlorite, clay minerals and quartz (Fig. 4). Opaque minerals either occurred as single euhedral to subhedral crystals, or as irregular aggregates composed of several to dozens of grains (Fig. 4c). Opaque minerals also filled the cracks present in the rock (Fig. 4d). This information led to the conclusion that the rock was cataclasite.

\subsection{Morphology and basic soil properties}

The soils located in the forested upper slope sections of both transects (GP1, GP2, PO1 and PO2) were characterised by the presence of organic horizons $(\mathrm{Ol}, \mathrm{Oe})$ with $\mathrm{SOC}$ reaching $38.8-41.4 \%$. They also had low $\mathrm{pH}$ values. Exchangeable acidity reached the highest values in these soils (1.4$11.7 \mathrm{cmol} \mathrm{kg}^{-1}$ ), whilst base saturation reached variable values in transects GP and PO of 5-38\% and 4-80\%, respectively. The soil texture in the discussed soil profiles was differential (Table 2). In GP1, it changed from silt loam to sandy loam, whilst in PO1, the texture varied from silt loam to loam. In turn, pedons GP2 and PO2 had a uniform silty loam texture. The main morphological feature of profiles GP1, GP2 and PO1 was the presence of a cambic horizon, whilst profile GP2 hosted colluvium material. The GP2 profile had recently been strongly reworked. 

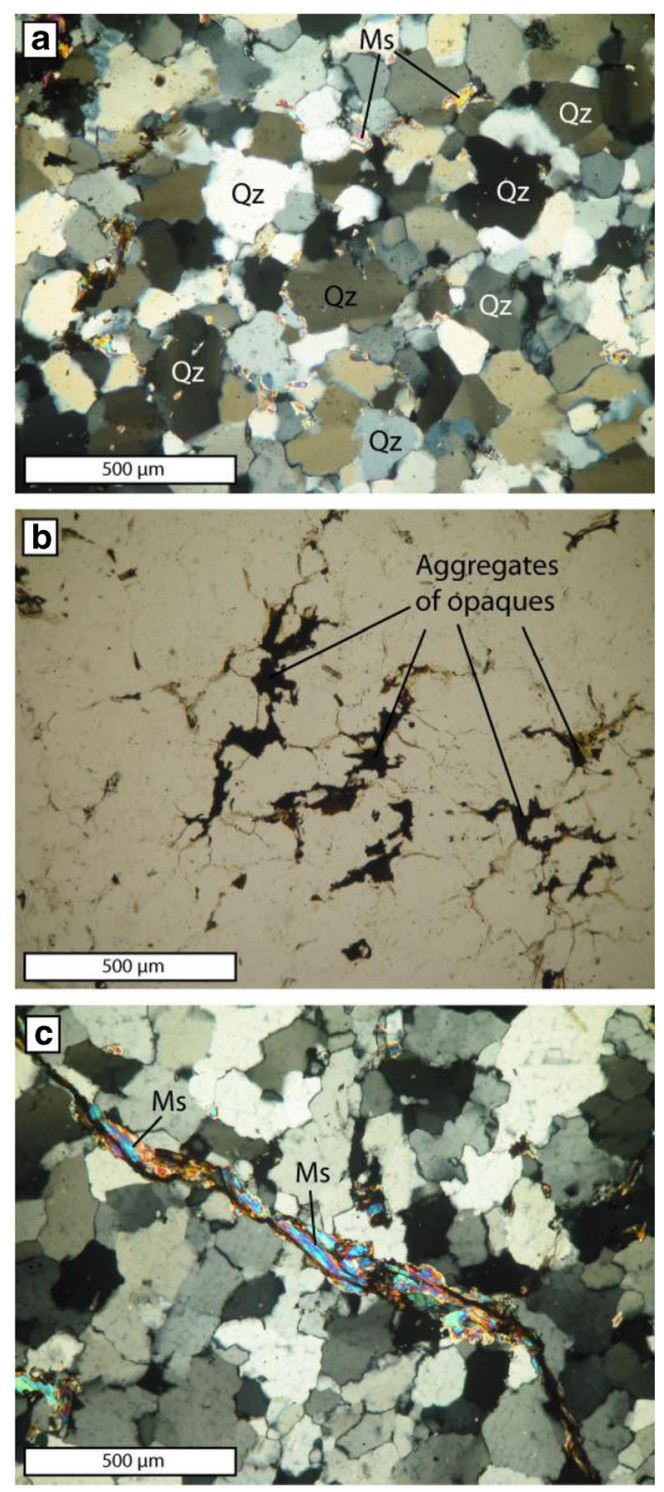

Fig. 3 Thin section of quartzite sampled from profile GP2

The soils from the lower slope sections (GP3, GP4, PO3 and PO4) were under the influence of agriculture. They were characterised by low SOC contents, reaching $0.1-3.2 \%$, and high $\mathrm{pH}$ values, from 5.1 to 6.9. The exchangeable acidity in these soils was low, reaching a maximum in GP3, of $1.4 \mathrm{cmol} \mathrm{kg}^{-1}$. Base saturation reached $99.8 \%$ in the Ap horizons, and decreased with depth to $86 \%$ in the Bt horizons. The soil texture in GP3 and GP4 was uniform silt loam; however, in PO3 and PO4, the texture changed from silt loam to loam. Profile GP3 was characterised by a very well-developed, reddish argic horizon, evidenced by the presence of clay at a depth of $57-130 \mathrm{~cm}$. Profile GP4 developed within colluvium material, with almost no sign of any coarse fractions, only single fragments of quartzite schist appearing just below the Ap horizon. Clay and clay-sesquioxide translocation, and the presence of clay cutans in the Btg horizon, were strongly manifested. Rainwater stagnation was recorded here in the lowermost part of the Ap horizon. The reductomorphic colours were 5 Y 6/1, whilst the oximorphic colours were $7.5 \mathrm{YR}$ 5/8. Also, profile PO3 showed features of water stagnation, expressed by the presence of stagnic properties in horizon 2Bg2 (oximorphic colour 5YR 5/8).

The reference profile, SL4, was classified as a Luvisol. It had a uniform silt loam texture, with clay cutans and $\mathrm{Fe} / \mathrm{Mn}$ nodules occurring in the Btg horizons.

\subsection{Geochemical composition of the studied soils}

The values of the major oxides in the studied soils were similar for both transects (Table 3 ). The GP and PO transects were characterised by $66.1-78.5 \% \mathrm{SiO}_{2}, 8.9-14.6 \% \mathrm{Al}_{2} \mathrm{O}_{3}, 3.2-$ $6.1 \% \mathrm{Fe}_{2} \mathrm{O}_{3}$ and $1.3-3.0 \% \mathrm{~K}_{2} \mathrm{O}$. However, differences in the soils were visible in the concentrations of $\mathrm{Zr}$ and $\mathrm{Hf}$ (Table 3 ). Pedons in the upper part of the slope of the GP transect contained 408.3-549 ppm Zr and 10.7-14.4 ppm Hf, whilst soils in the PO transect contained 359.6-377.1 ppm Zr and 9.4-10.0 ppm Hf. Soils from the lower parts of the slope in the GP transect consisted of 426.6-552.4 ppm and 11.6-14.8 ppm $\mathrm{Zr}$ and $\mathrm{Hf}$, respectively, whereas in the PO transect, the values of these elements were $298.5-382.6 \mathrm{ppm}$ and $7.4-10.0 \mathrm{ppm}$, respectively.

The reference soil profile, SL4, was characterised by similar values for the major oxides as in the studied soils, and $\mathrm{Zr}$ and $\mathrm{Hf}$ contents typical of aeolian silts (473.9 ppm and $12.4 \mathrm{ppm}$, respectively).

\section{Discussion}

\subsection{Soil texture evidence of aeolian silt admixing}

The rocks of the study area were predominantly recognised as being quartz schists, quartzites and greywackes (Sawicki 1995); however, one rock sampled from profile PO3 was found to be a cataclasite. In this manuscript, we refer only to the geological data referring to this profile, due to a lack of information in the literature about textures in soils formed from weathered cataclasite.

Three soil profiles were characterised by their uniform silt loam soil texture - GP2, GP3 and PO2. In the other profiles, the particle size distribution was more variable, usually indicating silt loam layers overlying loam-textured horizons. To verify whether residuum materials from the weathering of the crystalline rocks played an independent role as parent material, data on the soil texture in the studied pedons was compared with data from published studies. Thus, according to Rutherford and Sullivan (1970), Neely and Barkworth (1984) and Acosta et al. (2011), quartzite-derived materials have a sandy loam texture (Fig. 5a). Gago et al. (2012) found that soils formed from quartz-schist-derived materials also have a sandy loam 

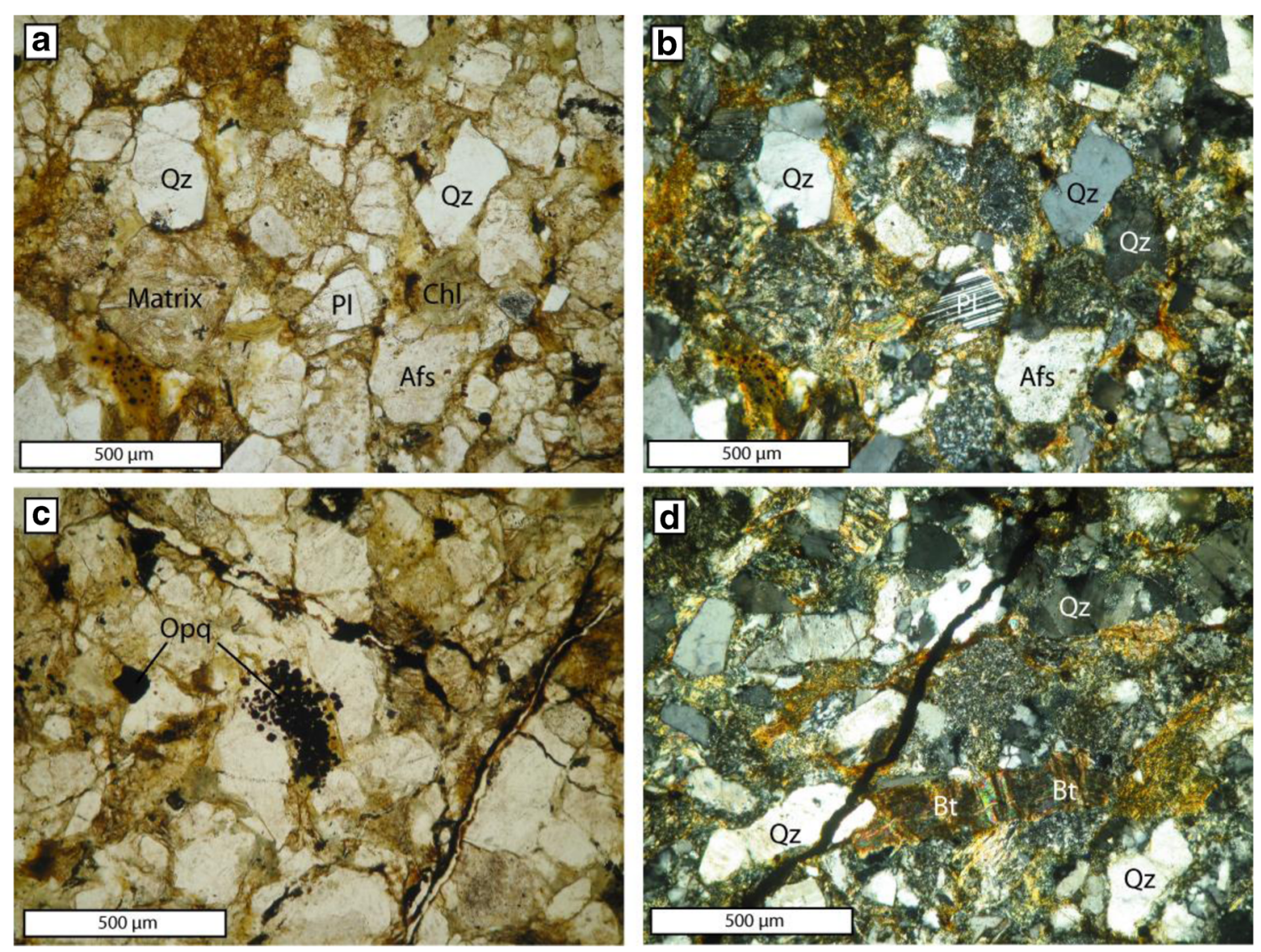

Fig. 4 Thin section of cataclasite sampled from profile PO3

texture. The products of weathering of rocks, according to the literature mentioned above, are characterised by the values of the respective fractions of sand (69-79\%), silt (8-20\%) and clay $(8-15 \%)$. However, in the studied soils, the contents of the soil fractions were different, with sand fractions oscillating between 12 and $56 \%$, silt between 39 and $75 \%$ and clay between 9 and 26\%. The studied soils contained a greater silt fraction than those formed exclusively from weathered greywacke or quartzite (Fig. 5a). In five of the pedons (GP1, GP4, PO1, PO3, PO4), the soil texture changed through the profile, with the texture of the upper horizons being dominated by silt, but with its content decreasing with depth, whilst the percentage of sand increased. These features can be explained by the fact that the residuum materials from the weathering of local rocks had a primarily sandy loam texture, but this had been mixed with allochthonous aeolian silt.

The presented results show that the studied soils were dominated by silt loam materials, especially in the topsoil, but that silt-sized dominant layers created thick mantles that served entirely as parent material for soil formation. Thus, we reject the assumption that the silt materials originated solely from the underlying local bedrock. The dominant silt texture suggests an incorporation of aeolian silt, likely related to the Last Glacial Maximum (LGM) loess deposition in the vicinity of the Opawskie Mountains (Jary 1999).

\subsection{Geochemical analysis as a proxy for aeolian silt admixing}

Loess materials are characterised by specific geochemical features that can be verified by a set of geochemical proxies (Rudnick and Gao 2003; Muhs and Benedict 2006; Feng et al. 2011; Ahmed and Chandra 2013; Lin and Feng 2015; Waroszewski et al. 2018a). To detect an aeolian impact on a soil, the immobile elements $\mathrm{Zr}$ and $\mathrm{Hf}$ are used; several studies have shown that soils formed from aeolian sediments, especially loess, are enriched in these elements (Ujvari et al. 2008; Ahmed and Chandra 2013; Scheib et al. 2014; Lin and Feng 2015; Waroszewski et al. 2018a). Hf and $\mathrm{Zr}$ are indicative of aeolian processes because they are characterised by very low mobility under most environmental conditions, mainly because of their high stability and the resistance of their host minerals, zircon and baddeleyite (De Vos and Tarvainen 2006). Median values of $\mathrm{Zr}$ and $\mathrm{Hf}$ in loess and loess-derived materials ranges from 237.0 to $453.0 \mathrm{ppm}$ and from 8.0 to $14.0 \mathrm{ppm}$, respectively (Scheib et al. 2014). The average loess value (AVL) for $\mathrm{Zr}$ is around $302.0 \mathrm{ppm}$, and for $\mathrm{Hf}$ it is $8.9 \mathrm{ppm}$ (McLennan 2001).

The geological data and rock thin sections have indicated that quartzites, quartz schists, greywackes and 
Table 2 Morphology and basic properties of soils under study

\begin{tabular}{|c|c|c|c|c|c|c|c|c|c|}
\hline Profile & Horizon & Depth $(\mathrm{cm})$ & $\mathrm{pH} \mathrm{H} \mathrm{H}_{2} \mathrm{O}$ & $\begin{array}{l}\text { Corg } \\
\%\end{array}$ & $\begin{array}{l}\text { Sand } \\
\%\end{array}$ & Silt & Clay & Texture group & $\begin{array}{l}\text { Rock fragments abundance } \\
\%\end{array}$ \\
\hline \multirow[t]{7}{*}{ GP1 } & $\mathrm{Ol}$ & $2-0$ & 4.6 & 38.8 & - & - & - & - & - \\
\hline & $\mathrm{AE}$ & $0-3$ & 3.8 & 17.4 & - & - & - & - & - \\
\hline & Bw1 & $3-35$ & 4.4 & 1.5 & 18 & 67 & 15 & Silt loam & - \\
\hline & Bw2 & $35-55$ & 4.4 & 0.76 & 28 & 56 & 16 & Silt loam & 20 \\
\hline & $2 \mathrm{BCg} 1$ & $55-70$ & 4.3 & 0.36 & 32 & 46 & 22 & Loam & 25 \\
\hline & 2(B)Cg2 & $70-85$ & 4.3 & 0.29 & 47 & 35 & 18 & Loam & 40 \\
\hline & $2 \mathrm{Cg}$ & $85-100$ & 4.2 & 0.27 & 56 & 28 & 16 & Sandy loam & 50 \\
\hline \multirow[t]{5}{*}{ GP2 } & $\mathrm{Ol}$ & $3-0$ & 3.7 & 41.4 & - & - & - & - & \\
\hline & $\mathrm{AE}$ & $0-5$ & 4.3 & 24.6 & 30 & 60 & 14 & Silt loam & 5 \\
\hline & Bw1 & $5-30$ & 4.3 & 079 & 20 & 62 & 18 & Silt loam & 5 \\
\hline & Bw2 & $30-54$ & 4.3 & 0.55 & 22 & 60 & 18 & Silt loam & - \\
\hline & $\mathrm{BC}$ & $54-80$ & 6.7 & 0.57 & 24 & 55 & 21 & Loam & - \\
\hline \multirow[t]{6}{*}{ GP3 } & Ap & $0-20$ & 6.5 & 1.3 & 15 & 70 & 15 & Silt loam & - \\
\hline & Apg1 & $20-30$ & 6.2 & 1.0 & 17 & 67 & 16 & Silt loam & - \\
\hline & $\mathrm{AEg}$ & $30-41$ & 6.1 & 0.61 & 17 & 67 & 16 & Silt loam & - \\
\hline & $\mathrm{Eg}$ & $41-57$ & 5.1 & 0.27 & 16 & 64 & 20 & Silt loam & - \\
\hline & $\mathrm{Btg}$ & $57-79$ & 5.1 & 0.15 & 14 & 62 & 24 & Silt loam & - \\
\hline & $\mathrm{Btg} / \mathrm{Eg}$ & 79-130 & 5.3 & 0.13 & 12 & 62 & 26 & Silt loam & - \\
\hline \multirow[t]{6}{*}{ GP4 } & Ap & $0-30$ & 6.9 & 1.2 & 18 & 70 & 12 & Silt loam & - \\
\hline & $\mathrm{Ag}$ & $30-55$ & 6.8 & 1.2 & 19 & 72 & 9 & Silt loam & - \\
\hline & $\mathrm{Eg}$ & $55-70$ & 6.5 & 0.84 & 15 & 75 & 10 & Silt loam & - \\
\hline & $\mathrm{Bg}(\mathrm{t})$ & $70-95$ & 6.7 & 0.79 & 20 & 70 & 10 & Silt loam & - \\
\hline & G1 & $95-120$ & 6.5 & 0.80 & 16 & 71 & 13 & Silt loam & - \\
\hline & G2 & $120-150$ & 6.4 & 0,96 & 13 & 72 & 15 & Silt loam & - \\
\hline \multirow[t]{6}{*}{ PO1 } & Od & $10-5$ & 4.3 & 39.9 & - & - & - & - & - \\
\hline & $\mathrm{Ah}$ & $5-0$ & 4.0 & 23.6 & 37 & 52 & 11 & Silt loam & 20 \\
\hline & $\mathrm{AB}$ & $0-5$ & 4.1 & 3.1 & 35 & 53 & 12 & Silt loam & 30 \\
\hline & Bw1 & $5-23$ & 4.6 & 0.87 & 35 & 55 & 10 & Silt loam & 55 \\
\hline & 2Bw2 & $23-50$ & 4.7 & 0.30 & 36 & 50 & 14 & Silt loam & 60 \\
\hline & $2 \mathrm{Bw} 3$ & $50-75$ & 4.5 & 0.36 & 37 & 47 & 16 & Loam & 60 \\
\hline \multirow[t]{4}{*}{ PO2 } & E & $2-20$ & 4.2 & 1.1 & 14 & 70 & 16 & Silt loam & 30 \\
\hline & EB & $20-30$ & 4.8 & 0.50 & 28 & 59 & 13 & Silt loam & 60 \\
\hline & $\mathrm{Bg} 1$ & $30-50$ & 4.9 & 0.24 & 21 & 64 & 15 & Silt loam & 60 \\
\hline & $\mathrm{Bg} 2$ & $50-75$ & 5.2 & 0.16 & 26 & 58 & 16 & Silt loam & 60 \\
\hline \multirow[t]{6}{*}{ PO3 } & A & $0-10$ & 5.7 & 3.2 & 31 & 58 & 11 & Silt loam & - \\
\hline & $\mathrm{AEg}$ & $10-20$ & 5.9 & 0.71 & 33 & 55 & 12 & Silt loam & - \\
\hline & $\mathrm{Eg}$ & $20-40$ & 5.9 & 0.48 & 33 & 56 & 11 & Silt loam & 45 \\
\hline & Ebg & $40-60$ & 6.0 & 0.28 & 39 & 44 & 17 & Loam & 50 \\
\hline & $2 \mathrm{Bg} 1$ & $60-72$ & 6.4 & 0.11 & 43 & 42 & 15 & Loam & 60 \\
\hline & $2 \mathrm{Bg} 2$ & $72-92$ & 6.2 & 0.20 & 51 & 39 & 10 & Loam & 65 \\
\hline \multirow[t]{4}{*}{ PO4 } & Ap & $0-20$ & 5.6 & 1.6 & 17 & 68 & 15 & Silt loam & 15 \\
\hline & EB & $20-35$ & 6.2 & 0.33 & 22 & 60 & 18 & Silt loam & 25 \\
\hline & Btg1 & $35-70$ & 6.0 & 0.21 & 23 & 56 & 21 & Silt loam & 20 \\
\hline & $2 \mathrm{Btg} 2$ & $70-105$ & 5.7 & 0.12 & 25 & 50 & 25 & Silt loam & 25 \\
\hline
\end{tabular}

cataclasites occur in the study area. The concentrations of $\mathrm{Zr}$ and $\mathrm{Hf}$ in quartzite-, greywacke- and cataclasite-derived materials reached $26.0-263.0 \mathrm{ppm}$ and $0.7-7.0 \mathrm{ppm}$, respectively (Table 3); however, geochemical analysis of the studied soils showed that the concentrations of $\mathrm{Zr}$ and $\mathrm{Hf}$ for silt-dominant materials were different from those 
Table 3 Comparison of $\mathrm{Zr}$ and $\mathrm{Hf}$ concentrations in weathered greywacke and quartzite substrates as well as in cataclasite and loess deposits

\begin{tabular}{|c|c|c|c|}
\hline Author & Parent material & $\begin{array}{l}\mathrm{Zr} \\
\mathrm{ppm}\end{array}$ & $\mathrm{Hf}$ \\
\hline Munroe et al. 2015 & Quartzite & 36.58 & 1.17 \\
\hline \multirow[t]{3}{*}{ French et al. 1997} & \multirow[t]{3}{*}{ Quartzite } & 98.00 & 2.55 \\
\hline & & 78.00 & 2.09 \\
\hline & & 111.00 & 2.79 \\
\hline \multirow[t]{4}{*}{ Linnemann and Romer 2002} & \multirow[t]{4}{*}{ Quartzite } & 208.00 & 6.00 \\
\hline & & 232.00 & 6.00 \\
\hline & & 188.00 & 5.00 \\
\hline & & 222.00 & 6.00 \\
\hline McLennan 2001 & Greywacke & 147.00 & 3.80 \\
\hline \multirow[t]{12}{*}{ Linnemann and Romer 2002} & \multirow[t]{12}{*}{ Greywacke } & 263.00 & 7.00 \\
\hline & & 214.00 & 6.00 \\
\hline & & 241.00 & 7.00 \\
\hline & & 192.00 & 5.00 \\
\hline & & 180.00 & 5.00 \\
\hline & & 232.00 & 6.00 \\
\hline & & 158.00 & 5.00 \\
\hline & & 211.00 & 5.00 \\
\hline & & 226.00 & 6.00 \\
\hline & & 195.00 & 5.00 \\
\hline & & 214.00 & 5.00 \\
\hline & & 251.00 & 6.00 \\
\hline \multirow[t]{4}{*}{ Lahtinen 2000} & \multirow[t]{4}{*}{ Greywacke } & 161.00 & 3.53 \\
\hline & & 190.00 & 4.63 \\
\hline & & 150.00 & 3.91 \\
\hline & & 144.00 & 3.5 \\
\hline Liu et al. 2017 & Cataclasite & 26.0 & 0.70 \\
\hline \multirow[t]{8}{*}{ Yamaguchi et al. 2014} & \multirow[t]{8}{*}{ Cataclasite } & 96.60 & 2.91 \\
\hline & & 84.90 & 2.60 \\
\hline & & 99.80 & 2.94 \\
\hline & & 101.00 & 3.03 \\
\hline & & 58.60 & 1.87 \\
\hline & & 78.5 & 2.34 \\
\hline & & 90.70 & 2.62 \\
\hline & & 106.00 & 3.15 \\
\hline McLennan 2001 & $\mathrm{AVL}^{*}$ & 302.00 & 8.90 \\
\hline Scheib et al. 2014 & Loess & $280.00-440.00$ & $7.00-13.00$ \\
\hline \multirow[t]{2}{*}{ Pasquini et al. 2017} & Ap horizon in loess & 296.00 & 8.90 \\
\hline & Bw horizon in loess & 294.00 & 9.60 \\
\hline
\end{tabular}

geochemical characteristics typical of the underlying local bedrock (Table 4). The soils in the GP transect contained 426.0-549.0 ppm $\mathrm{Zr}$ and 10.7-14.8 ppm Hf. In the PO transect, the values of $\mathrm{Zr}$ and $\mathrm{Hf}$ were slightly lower, at 274.4-382.6 ppm and 7.4-10.4 ppm, respectively. For comparison, the reference soil profile, SL4, had Zr and Hf reaching $473.9 \mathrm{ppm}$ and $12.4 \mathrm{ppm}$, respectively. The concentrations of $\mathrm{Zr}$ and $\mathrm{Hf}$ in the studied soils are twofold to fourfold higher than the data for greywacke- or quartzitederived substrates, as provided by French et al. (1997), Lahtinen et al. (2000) and Linnemann and Romer (2002).

The concentrations of $\mathrm{Zr}$ and $\mathrm{Hf}$ in transect $\mathrm{PO}$ were lower than in GP because of the topographic conditions. Transect GP was located on a slope where there were no topographic barriers for silt deposition; however, transect PO was surrounded by individual hills that could have 
Fig. 5 Grain size composition in a soils developed from greywacke- and quartzits-derived materials and studied loessinfluenced soils and $\mathbf{b}$ in designated layers in studied soils
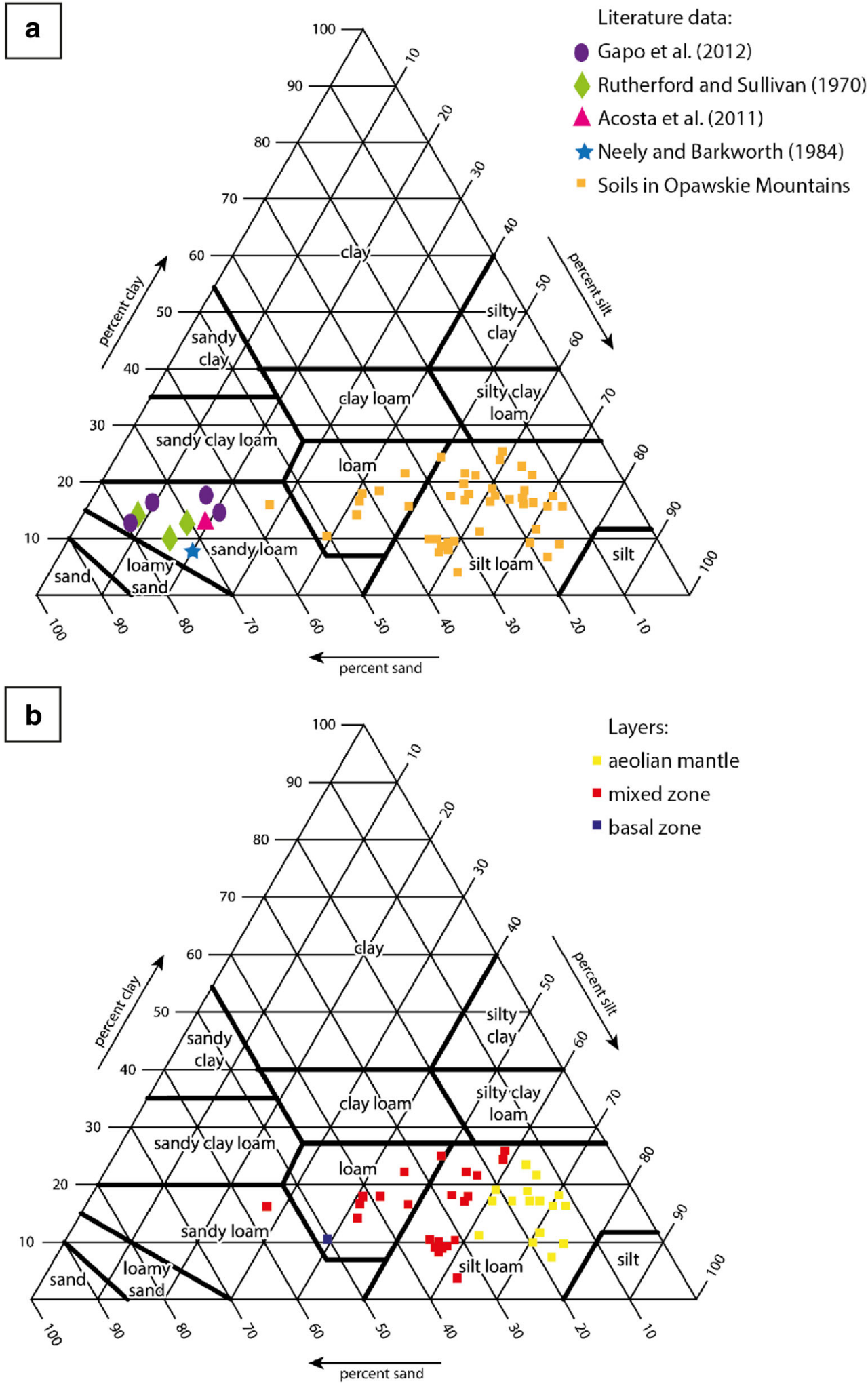

aided aeolian silt transportation and accumulation. During the LGM in southern Poland, a north-east wind direction predominated (Rousseau and Sima 2014; Marks et al. 2016, 2019); thus, transect GP was more exposed to silt deposition, and its accumulation was higher (based on the remnants of thick loess mantles), whereas PO was likely more protected, and its rates of silt deposition were probably relatively reduced. 
Ratios and bivariate plots of the immobile elements $(\mathrm{Zr} /$ $\mathrm{Hf}, \mathrm{Zr} / \mathrm{V}$ vs. Th/V) provide a useful method for identifying multiple parent materials in soil profiles (Muhs and Benedict 2006; Munroe et al. 2007) (Table 4). The relative proportions of immobile elements should be the same, or the concentrations should have similar patterns, in the bedrock as well as in the overlying horizons, if the bedrock is considered to be a uniform and homogenous material for soil development. Figure 6 shows the linear relation between $\mathrm{Zr}$ and $\mathrm{Hf}$ in the studied soils and the materials produced by the weathering of rocks. The data related to the studied pedons are clustered together, and the values of $\mathrm{Zr}$ and $\mathrm{Hf}$ ranged from 274.4 to $549.0 \mathrm{ppm}$ and 7.4 to $14.8 \mathrm{ppm}$, respectively for this group. The highest $\mathrm{Zr}$ and $\mathrm{Hf}$ contents were represented in the topmost horizons of profiles GP1, PO2 and PO4, and in all of the horizons from profiles GP2, GP3 and GP4. The data in the middle of Fig. 6 refers to profile PO1, the upper horizons of pedon PO3 and the lower horizons of profiles GP1, PO2 and PO4. The lowest $\mathrm{Zr}$ and $\mathrm{Hf}$ contents were noted in the lowest horizon of profile PO3 (Fig. 2). The values of $\mathrm{Zr}$ and $\mathrm{Hf}$ for the AVL and profile SL4 are in the same group as those of the studied soils. Data derived from weathered quartzite, greywacke and cataclasite formed a second cluster, with noticeably lower concentrations of the elements (26.0 $263.0 \mathrm{ppm} \mathrm{Zr}, 0.7-7.0 \mathrm{ppm} \mathrm{Hf}$ ). In Fig. 7 (Th/V vs. Zr/ V), data related to the studied soils formed a cluster together with the AVL and SL4 values. In general, profiles GP2, GP3 and GP4 and the upper horizons of profiles PO2 and PO4 have the highest values on this chart. Profiles PO1 and $\mathrm{PO} 3$ and the subsoil in pedons GP1, PO2 and PO4 are characterised by slightly lower values, but these are still significantly higher than the concentrations in the underlying local bedrock materials, which occur on the opposite side in Fig. 7. The bivariate plot of the major oxides $\left(\mathrm{Na}_{2} \mathrm{O} / \mathrm{Al}_{2} \mathrm{O}_{3}\right.$ vs. $\left.\mathrm{K}_{2} \mathrm{O} / \mathrm{Al}_{2} \mathrm{O}_{3}\right)$ can be used to distinguish in situ quartzite and schist material from aeolian deposits because the studied soils are tightly clustered together. Figure 8 illustrates the data from the studied soils, which is located in one area of the diagram, again forming a tight cluster with similar values, whereas the values for the schist-, quartzite- and cataclasite-derived materials are irregularly arranged on the plot.

The presented results show that the concentrations of the compared elements, and the ratios and bivariate plots of the studied soils, are noticeably different from those geochemical parameters of materials derived from the weathering of quartzites and greywackes. Thus, we can assume the presence of an aeolian silt contribution (Muhs and Benedict 2006; Munroe et al. 2007; Ujvari et al. 2008; Ahmed and Chandra 2013; Scheib et al. 2014; Waroszewski et al. 2018a). The concentrations of the indicative elements $\mathrm{Zr}$ and $\mathrm{Hf}$ are similar to those presented for loess; therefore, aeolian silt played a key role in soil formation in the Opawskie Mountains. The bivariate plots of the major chemical compounds $\left(\mathrm{Na}_{2} \mathrm{O} / \mathrm{Al}_{2} \mathrm{O}_{3}\right.$ vs. $\mathrm{K}_{2} \mathrm{O} /$ $\mathrm{Al}_{2} \mathrm{O}_{3}$ and $\mathrm{Th} / \mathrm{V}$ vs. $\mathrm{Zr} / \mathrm{V}$ ) also indicate an affinity of the studied soils to aeolian silt, rather than to in situ-derived materials. It is worth noting that geochemical analysis has proven that the aeolian contribution to soils can be deeper than expected in field studies.

\subsection{Designation of aeolian mantles, mixed zones and basal zones based on soil texture and geochemistry}

Based on morphological (Table 1), textural and geochemical data (Table 4), three layers were distinguished. They show different contributions of aeolian silt to the studied soils (Figs. 5 and 6), including the following:

1. an aeolian mantle containing $>410 \mathrm{ppm} \mathrm{Zr}$ and $>$ $11.5 \mathrm{ppm}$ Hf, with silt reaching at least $60 \%$ and rock fragment abundance being $<20 \%$;

2. a mixed zone where $\mathrm{Zr}$ reaches $295-410 \mathrm{ppm}$ and $\mathrm{Hf} 8$ $11.5 \mathrm{ppm}$, with a silt fraction reaching $40-60 \%$ and rock fragment abundance being 20-40\%; and

3. a basal zone with $\mathrm{Zr}$ and $\mathrm{Hf}$ being $<295 \mathrm{ppm}$ and $<$ 8 ppm, respectively, with silt contributing $<40 \%$ and rock fragments $>60 \%$.

Soils from the GP transect that were located in the upper slope positions that had two layers. Pedon GP1 had a thin $(32 \mathrm{~cm})$ aeolian mantle overlying a thick mixed zone $(65 \mathrm{~cm})$, whereas soil GP2 consisted of a thick aeolian mantle through the entire profile. The soil profiles located in the lower slope sections, GP3 and GP4, developed uniformly within thick loess deposits, with a clear dominance of silt (60-75\%) and the highest immobile element values (Zr 426.6-552.4 ppm; Hf 11.6-14.8 ppm); these layers represent thick aeolian mantles. In soils developed in the PO transect, the layer features were different. Pedon PO1, located on the highest part of the slope, formed in a mixed zone, having a thickness of ca. $75 \mathrm{~cm}$, whereas PO2, located on the middle part of the slope, was characterised by a thin mixed zone $(48 \mathrm{~cm})$. Profile PO3, situated on the lower slope, revealed different characteristics, having developed in a thick mixed zone $(72 \mathrm{~cm})$, overlying a thin basal zone $(20 \mathrm{~cm})$. This basal zone was the only example among all the studied layers having clear residuum signatures, very low silt contents and relatively low $\mathrm{Zr}$ and $\mathrm{Hf}$ (below $280 \mathrm{ppm}$ and $8 \mathrm{ppm}$, respectively). Pedon PO4, from the lower part of the slope, also consisted of two layers - a thin aeolian mantle $(35 \mathrm{~cm})$ in the upper part of the profile and a thick mixed zone $(70 \mathrm{~cm})$ in the bottom part. 
Table 4 Major and trace elements in representative horizons of studied soils and reference profile

$\begin{array}{lllllllllllllllllll}\text { Profile Horizon } & \mathrm{SiO}_{2} & \mathrm{Al}_{2} \mathrm{O}_{3} & \mathrm{Fe}_{2} \mathrm{O}_{3} & \mathrm{MgO} & \mathrm{CaO} & \mathrm{Na}_{2} \mathrm{O} & \mathrm{K}_{2} \mathrm{O} & \mathrm{TiO}_{2} & \mathrm{P}_{2} \mathrm{O}_{5} & \mathrm{MnO} & \mathrm{Cr}_{2} \mathrm{O}_{3} & \mathrm{Zr} & \mathrm{Hf} & \mathrm{Th} & \mathrm{V} & \mathrm{Y}\end{array}$ (\%) (ppm)

\begin{tabular}{|c|c|c|c|c|c|c|c|c|c|c|c|c|c|c|c|c|c|}
\hline GP1 & Bw2 & 75.1 & 9.2 & 4.1 & 0.54 & 0.23 & 0.45 & 1.9 & 0.76 & 0.23 & 0.19 & 0.01 & 478.8 & 12.3 & 9.7 & 74.0 & 30. \\
\hline GP1 & 2BCg1 & 74.8 & 10.6 & 4.6 & 0.71 & 0.23 & 0.49 & 1.9 & 0.73 & 0.20 & 0.09 & 0.01 & 408.3 & 10.7 & 11.4 & 84.0 & 41. \\
\hline GP1 & $2 \mathrm{Cg}$ & 71.7 & 11.0 & 8.1 & 0.41 & 0.05 & 0.08 & 1.3 & 0.60 & 0.41 & 0.20 & 0.02 & 454.5 & 11.5 & 12.6 & 125.0 & 60. \\
\hline GP2 & Bw1 & 76.9 & 9.6 & 3.4 & 0.59 & 0.24 & 0.58 & 2.2 & 0.81 & 0.09 & 0.08 & 0.01 & 527.3 & 13.6 & 11.7 & 64.0 & 26. \\
\hline GP2 & $\mathrm{BC}$ & 78.5 & 9.1 & 3.2 & 0.53 & 0.24 & 0.60 & 2.2 & 0.83 & 0.10 & 0.11 & 0.01 & 549.0 & 14.4 & 9.5 & 63.0 & 28. \\
\hline SP3 & Ap & 75.9 & 8.9 & 3.6 & 0.58 & 0.58 & 0.74 & 2.2 & 0.83 & 0.16 & 0.11 & 0.01 & 500.2 & 13.1 & 10.3 & 67.0 & 26. \\
\hline SP3 & $\mathrm{Eg}$ & 77.2 & 9.7 & 3.6 & 0.62 & 0.43 & 0.84 & 2.5 & 0.83 & 0.08 & 0.10 & 0.01 & 520.6 & 13.6 & 11.0 & 64.0 & \\
\hline SP3 & Ebtg & 74.9 & 10.7 & 3.9 & 0.78 & 0.43 & 0.80 & 2.5 & 0.80 & 0.09 & 0.08 & 0.01 & 449.6 & 11.9 & 10.7 & 73.0 & \\
\hline GP3 & $\mathrm{Btg} / \mathrm{Eg}$ & 74.2 & 10.9 & 4.4 & 0.83 & 0.45 & 0.79 & 2.3 & 0.77 & 0.10 & 0.07 & 0.01 & 426.6 & 11.6 & 11.0 & 74.0 & . \\
\hline GP4 & $\mathrm{Ag}$ & 76.6 & 8.8 & 3.4 & 0.58 & 0.61 & 0.67 & 2.1 & 0.80 & 0.13 & 0.15 & 0.01 & 507.8 & 12.8 & 10.3 & 65.0 & \\
\hline SP4 & $\mathrm{Eg}$ & 77.5 & 8.8 & 3.4 & 8 & 0.52 & 0.72 & 2.2 & 0.82 & 0.09 & 0.15 & 0.01 & 552.4 & 14.8 & 10.6 & 65.0 & \\
\hline GP4 & G1 & 77.9 & 8.8 & 3.2 & 0.62 & 0.47 & 0.68 & 2.2 & 0.81 & 0.09 & 0.08 & 0.01 & 519.6 & 13.4 & 10.7 & 61.0 & t. \\
\hline PO1 & 2Bw2 & 68.0 & 14.5 & 5.3 & 1.60 & 0.25 & 1.28 & 3.0 & 0.99 & 0.09 & 0.10 & 0.01 & 365.8 & 9.4 & 10.3 & 108.0 & \\
\hline PO1 & 2Bw3 & 67.8 & 14.6 & 5.4 & 1.60 & 0.23 & 1.24 & 3.0 & 1.00 & 0.11 & 0.11 & 0.01 & 375.7 & 9.7 & 10.7 & 110.0 & 30. \\
\hline PO2 & EB & 66.1 & 14.1 & 5.5 & 1.38 & 0.22 & 1.17 & 2.6 & 0.92 & 0.11 & 0.10 & 0.01 & 359.6 & 9.6 & 11.2 & 108.0 & \\
\hline PO2 & $\mathrm{Bg} 2$ & 68.3 & 13.8 & 5.6 & 1.38 & 0.38 & 1.21 & 2.8 & 0.90 & 0.12 & 0.10 & 0.01 & 377.1 & 10.0 & 11.3 & 99.0 & \\
\hline PO3 & $\mathrm{Eg}$ & 73.1 & 11.5 & 4.4 & 1.06 & 0.40 & 1.07 & 2.4 & 0.79 & 0.11 & 0.09 & 0.01 & 382.6 & 10.0 & 10.3 & 84.0 & \\
\hline PO3 & Ebg & 71.6 & 12.1 & 5.4 & 1.33 & 0.34 & 1.04 & 2.5 & 0.72 & 0.09 & 0.10 & 0.01 & 311.8 & 8.5 & 9.6 & 96.0 & \\
\hline PO3 & $2 \mathrm{Bg} 2$ & 70.1 & 12.9 & 5.7 & 1.36 & 0.41 & 1.02 & 2.5 & 0.73 & 0.10 & 0.11 & 0.01 & 274.7 & 7.4 & 10.3 & 96.0 & \\
\hline PO4 & EB & 68.7 & 13.5 & 5.7 & 1.24 & 0.34 & 1.08 & 2.5 & 0.85 & 0.07 & 0.12 & 0.01 & 323.1 & 8.9 & 11.2 & 99.0 & 3 \\
\hline PO4 & $2 \mathrm{Btg} 2$ & 66.9 & 14.4 & 6.1 & 1.38 & 0.38 & 1.21 & 2.5 & 0.85 & 0.10 & 0.13 & 0.01 & 298.5 & 8.2 & 11.5 & 108.0 & 0 \\
\hline SL4* & Btg2 & 76.1 & 10.1 & 3.8 & 0.85 & 0.66 & 0.98 & 2.4 & 0.77 & 0.11 & 0.07 & 0.01 & 473.9 & 12.4 & 11.1 & 62.0 & 3 \\
\hline
\end{tabular}

*Reference profile for studied area

Generally, the geochemistry and soil texture, as proxies for aeolian silt admixing in the soils, produced consistent results, allowing the distinction of layers with differential inputs of loess materials. In cases where the geochemistry and grain-size composition data described the same material as being two different layers, however, the geochemistry
Fig. 6 Plot of Zr vs. Hf,

comparing concentration in aeolian-influenced soils and materials derived from quartzites, greywackes and cataclasites (Muhs and Benedict 2006; Ahmed and Chandra 2013; Scheib et al. 2014)

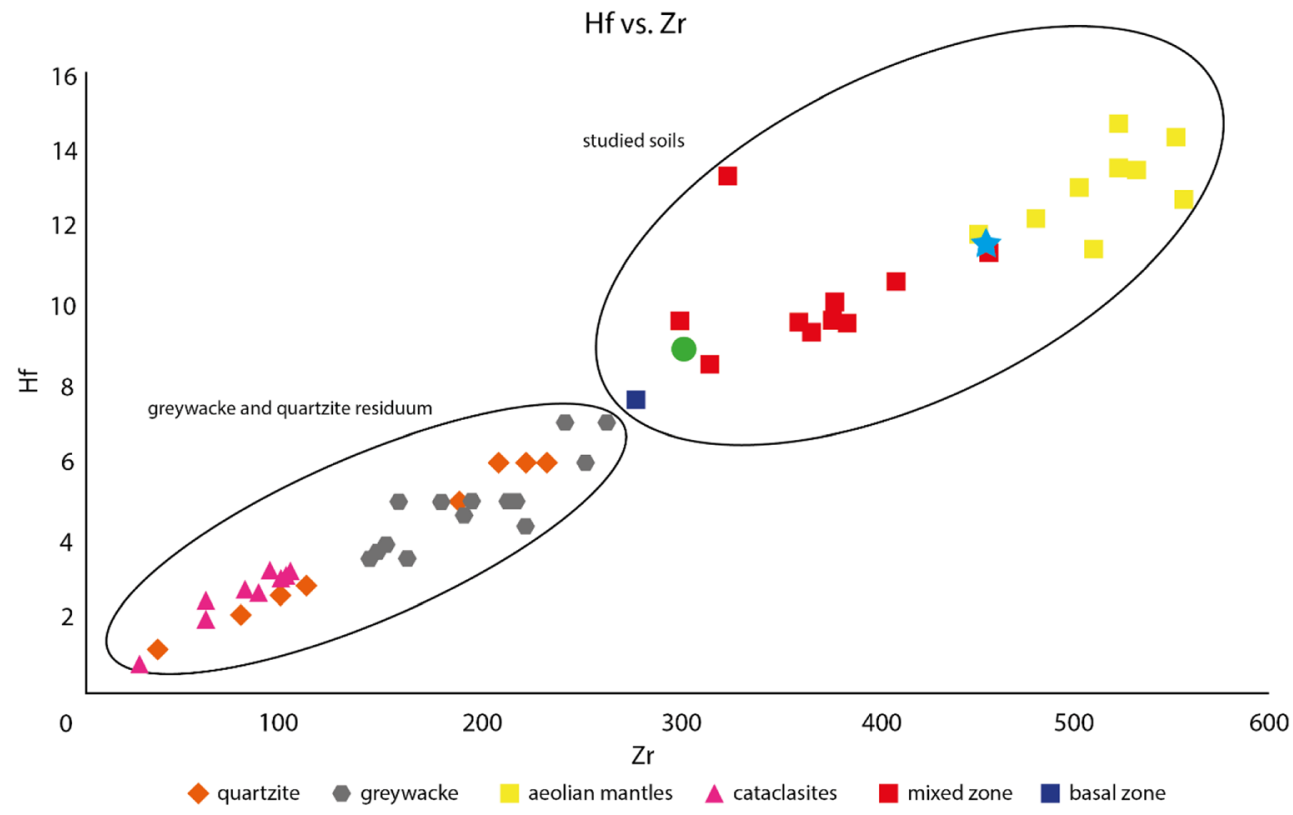

AVL SL4 
Fig. 7 Bivariate plot of $\mathrm{Zr} / \mathrm{V}$ vs. $\mathrm{Th} / \mathrm{V}$ in studied soils and materials/soils derived from quartzites, greywackes and cataclasites (Munroe et al. 2007; Ujvari et al. 2008; Ahmed and Chandra 2013)
$\mathrm{Zr} / \mathrm{V}$ vs. Th/ $\mathrm{V}$

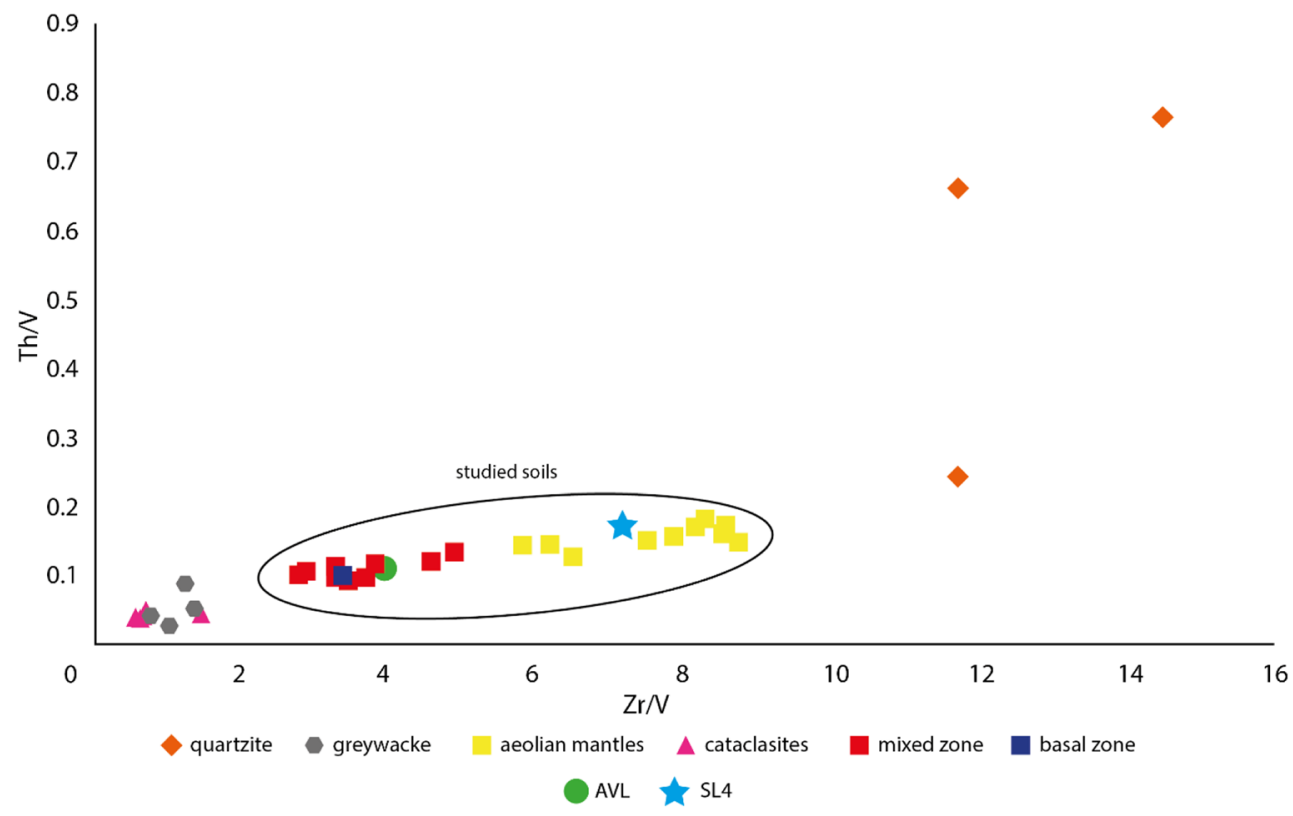

should be used as the deciding proxy (Waroszewski et al. 2019). In the studied soils, one such inconsistent case occurred in profile GP1, in horizon $2 \mathrm{Cg}$, where the silt content reached only $28 \%$, and this horizon was supposed to be assigned to the basal zone. The geochemical analysis showed a strong influence of aeolian silt, with concentrations of $\mathrm{Zr}$ and Hf reaching $454.4 \mathrm{ppm}$ and $11.5 \mathrm{ppm}$, respectively. In this case, we considered this proxy to be crucial, and designated this horizon as a mixed zone, due to the fact that it was characterised by a strong influence of aeolian silt, and not weathered bedrock.

\subsection{Soil formation in a mountainous area with an aeolian silt influence}

Typically, the regoliths of various parent rock types on mountain slopes in more loamy materials host weakly developed soils, such as Leptosols, Regosols and Cambisols (Kabala et al. 2015; Waroszewski et al. 2018a). However, the deposition of loess modifies the conditions of soil formation (Waroszewski et al. 2018a). Aeolian silt is usually enriched in carbonates, as are soils formed from this material. Climates dominated by dissolution-precipitation processes promote the

Fig. 8 Bivariate plot of $\mathrm{Na}_{2} \mathrm{O} /$ $\mathrm{Al}_{2} \mathrm{O}_{3}$ vs. $\mathrm{K}_{2} \mathrm{O} / \mathrm{Al}_{2} \mathrm{O}_{3}$ distinguishing quartzite, cataclasite and schist materials from studied soils with aeolian silt admixture (Munroe et al. 2007; Ujvari et al. 2008; Ahmed and Chandra 2013)

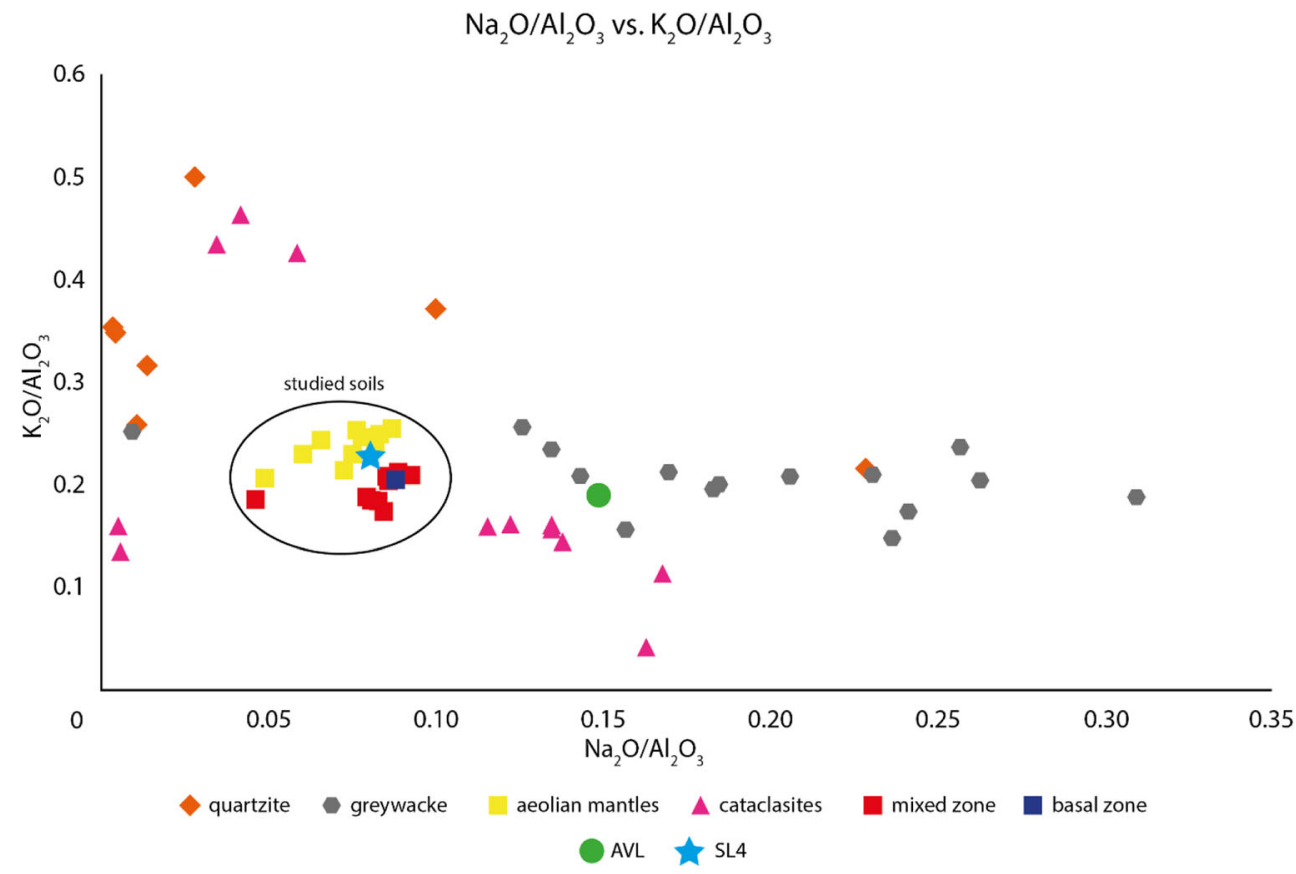



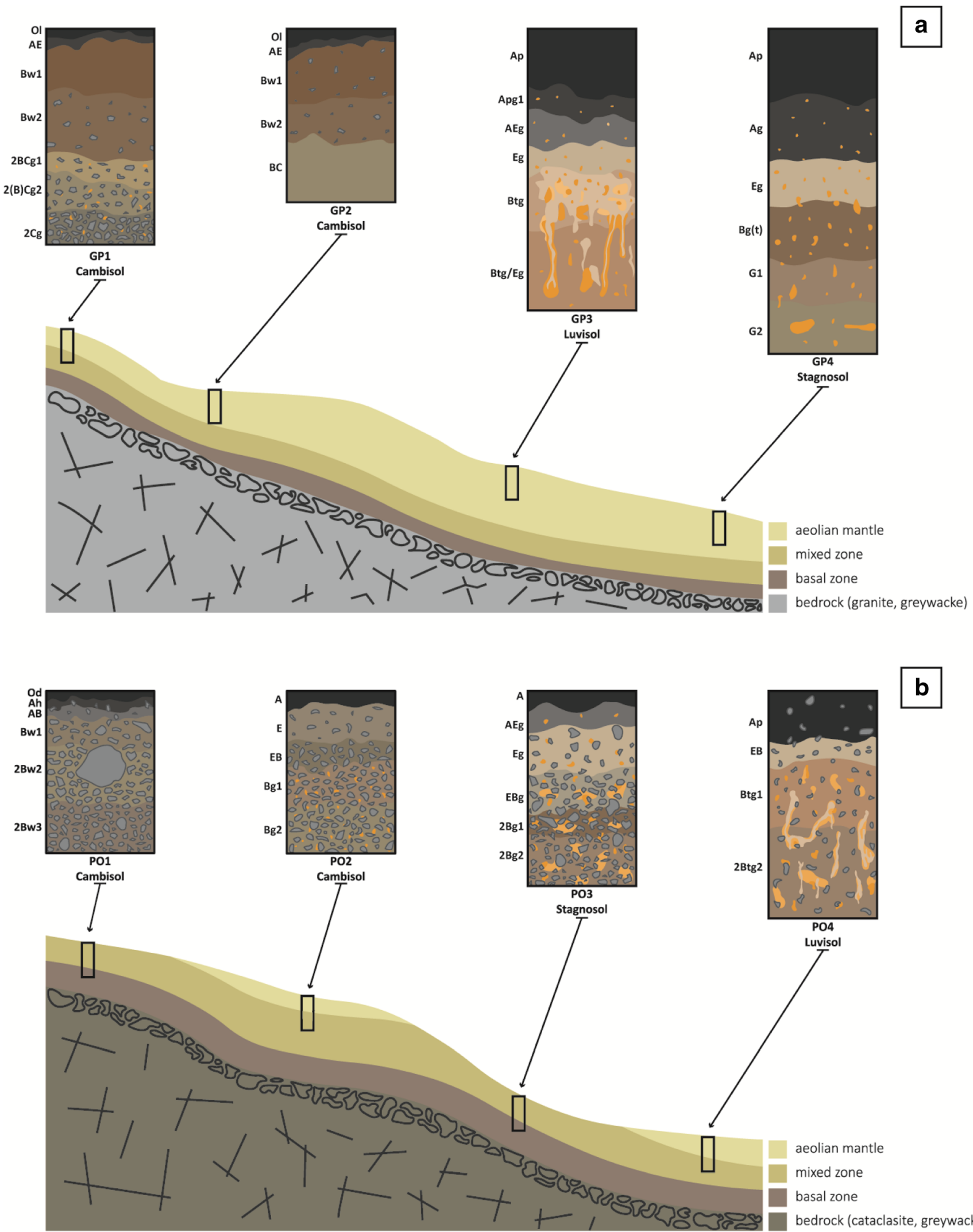

aeolian mantle

mixed zone

basal zone

bedrock (cataclasite, greywacke)

Fig. 9 Scheme of soil formation in mountainous area of the Opawskie Mountains influenced by aeolian silt admixture

accumulation of materials transported from the upper soil horizons to lower, enriched horizons (Bw and $\mathrm{Bt}$ ). Clay illuviation is noticeable in a diagnostic (argic) horizon (Pasquini et al. 2017). Due to the properties of aeolian silt, 
its admixture as an allochthonous material in a mountain ecosystem supports the processes of pedogenesis (Lin and Feng 2015).

The soils located in the upper parts of the slopes were classified as Cambisols (GP1, GP2, PO1, PO2). These Cambisols were characterised by $50-60-\mathrm{cm}$-thick aeolian mantles/mixed zones, with well-structured cambic horizons $(\mathrm{Bw})$. The profile GP2 was characterised by aeolian mantle throughout the entire profile. The possible reason for this Cambisol formation is that Luvisol likely developed within the thick, pure aeolian silt cover, whilst recent silts were strongly reworked (tree-throws) and eroded, and therefore, with the silt mantle remnants among short time-split, only Cambisol formation was possible. The pedons from the lower (middle and toe) parts of the slopes were formed in thick loess covers (more than $2 \mathrm{~m}$ thick), and were classified as Luvisols (PO4, SL4) with well-developed argic horizons (GP3), or as Stagnosols (GP4, PO3) where the profile was located in a foot slope zone.

Based on the obtained results, a hypothetical scheme for soil formation in mountainous areas, influenced by aeolian silt admixing, can be proposed (Fig. 9). From the materials formed by the weathering of quartzite, greywacke or cataclasite, Regosol or Leptosol were developed. However, in the Pleistocene, during glacial events, the deposition rates of aeolian silt were greater than in the present interglacial period (Muhs 2013). The most intense deposition of aeolian material occurred during the LGM (Weichselian; Jary 1996). Hence, the quartzite-, greywacke- and cataclasite-derived regoliths located on the slopes were involved in weak to moderate aeolian admixing. Following the accumulation of aeolian silt on the slopes, erosion processes likely started at the end of the Pleistocene, providing the foot and toe slopes with colluvial material, and increasing the thickness of the aeolian silt deposits. An intensification of the erosion may also have been triggered by deforestation and changes in land use by Neolithic agricultural tribes in the Atlantic Period, ca. 6-5 ka BC (Zygmunt 2009). Such processes may have caused the colluviation (Poręba et al. 2015; Zádorová and Penížek 2018) of aeolian silts from the shoulder to the middle and foot slopes. As a result, Cambisols may have formed within an aeolian mantle/mixed zone on the shoulder of the slope and on the middle slope through the reduction of previously thick aeolian mantles (profile GP2), or they received only a weak loess contribution. In the middle slopes, within the deeper loess deposits, well-developed Luvisols developed, whilst in the foot slopes, Stagnosols occurred, formed from reworked loess strata under the influence of rainwater stagnation (Fig. 9).

These potential pathways for soil evolution, variously impacted by aeolian silt trajectories, might relate to the results presented by Kufmann (2003) from the high mountainous karst of the Wetterstein Mountains (Northern Calcareous Alps). Here, mostly Cambisols on limestone residuum materials were studied, in the presence of local, coarse-grained aeolian silts and far-dust accumulations. These were formed within thin loess mantles, which, together with the carbonates, prevented clay translocation and provided conditions suitable for cambic horizon development. This supports the hypothesis that a weak aeolian contribution to the soil is responsible for Cambisol development (Waroszewski et al. 2018a). Also, Martignier et al. (2015) reported the occurrence of Cambisols and the formation of Luvic Cambisols in the Swiss Jura Mountains, assessed based on local aeolian silts in direct relation to decreasing carbonate content. The direction of pedogenesis in deep loess deposits and soils hosting moderate aeolian silt admixtures supports the observations of Waroszewski et al. (2018a) - that it leads to the formation of Luvisols, Retisols and Stagnosols in reworked loess.

\section{Conclusions}

Our study demonstrates that the soils developed in the Opawskie Mountains are characterised by aeolian silt admixtures, which differentiates them from typical soils developed from materials exclusively formed during the in situ weathering of the underlying bedrock. Geochemical composition and soil texture clearly distinguish aeolian silts from weathered quartzites, greywackes and cataclasites. The studied pedons had silt grain-size compositions typical of loess, but not local residuum materials associated with the bedrock. Geochemical signatures, such as $\mathrm{Zr}$ and $\mathrm{Hf}$ content, and bivarate plots confirmed an aeolian origin for the predominantly silty material. Thus, materials from the weathering of bedrock did not play an independent role as a parent material for the studied pedons. Instead, aeolian silt was admixed with, or totally replaced, the already existing autochthonous material. Different degrees of aeolian silt incorporation controlled the soil development, and resulted in the occurrence of very well-developed Luvisols, Stagnosols (with at least a moderate aeolian silt contribution) and Cambisols (revealing a weak admixture). The soil types distinguished could not have been formed by the weathering of quartzites or greywackes because they provide a much less structure-forming medium for soils, but are also characterised by much smaller clay-sized components, which prevents the formation of soils with prominent clay accumulation features.

Acknowledgements The authors are grateful to Joanna Kowalska, Jakub Piotrowiak and Elżbieta Musztyfaga for help during the fieldwork. This study was done within the framework of Soil Science Student Scientific Group (Wroclaw University of Environmental and Life Sciences). Three anonymous reviewers are appreciated for constructive comments that improved final version of the manuscript.

Funding information This research was financed by the National Science Center (Poland) project number 2014/15/D/ST10/04087 as well as by Wroclaw University of Environmental and Life Sciences, project number D210/0021/18 and B030/0018/18. 
Open Access This article is distributed under the terms of the Creative Commons Attribution 4.0 International License (http:// creativecommons.org/licenses/by/4.0/), which permits unrestricted use, distribution, and reproduction in any medium, provided you give appropriate credit to the original author(s) and the source, provide a link to the Creative Commons license, and indicate if changes were made.

\section{References}

Acosta JA, Martinez-Martinez S, Faz A, Arocena J (2011) Accumulations of major and trace elements in particle size fractions of soils on eight different parent materials. Geoderma 161:30-42

Ahmad I, Chandra R (2013) Geochemistry of loess-paleosol sediments of Kashmir Valley, India: Provenance and weathering. J Asia Earth Sci 66:73-89

Bac S, Rojek M (2012) Meteorologia i klimatologia w inżynierii środowiska. Wydawnictwo Uniwersytetu Przyrodniczego we Wrocławiu, Wrocław

Badura J, Jary Z, Smalley I (2013) Sources of loess material for deposits in Poland and parts of Central Europe: the lost big river. Quatern Int 296:15-22

De Vos W, Tarvainen T (2006) Interpretation of geochemical maps, additional tables, figures, maps and related publications. In: De Vos W, Tarvainen T (eds) Geochemical atlas of Europe. Part 2. Otamedia Oy, Espoo 690 pp

Dokuchaev VV (1967) Russian Chernozem, in selected works of V. V. Dokuchaev, Moscow, 1948, 1, 14 419. Israel Program for Scientific Translations Ltd. (for USDA- NSF), Publ. by S. Monson, Jerusalem (Transl. into English by N. Kaner)

FAO (ed) (2006) Guidelines for soil description, 4rd edn. FAO, Rome

Feng JL, Hu ZG, Ju JT, Lin YC (2014) The dust provenance and transport mechanism for the Chengdu clay in the Sichuan Basin, China. Catena 121:68-80

Feng J-L, Hu Z-G, Ju J-T, Zhu L-P (2011) Variations in trace element (including rare earth element) concentrations with grain sizes in loess and their implications for tracing the provenance of eolian deposits. Quat Int 236(1-2):116-126

French BM, Koeberl C, Gilmour I, Shirey SB, Dons JA, Naterstad J (1997) The Gardons impact structure, Norway: petrology and geochemistry of target rocks and impactites. Geochim Cosmochim Acta 61(4):873-904

Gago C, Romar A, Fernandez-Marcos ML, Alvarez E (2012) Fluorine sorption by soils developed from various parent materials in Galicia (NW Spain). J Colloid Interface Sci 374:232-236

Gild C, Geitner C, Sanders D (2018) Discovery of a landscape-wide drape of late-glacial aeolian silt in the western Northern Calcareous Alps (Austria): first results and implications. Geomorphology 301:39-52

Haase D, Fink J, Haase G, Ruske R, Pecsi M, Richter H, Altermann, Jager K-D (2007) Loess in Europe -its spatial distribution based on a European Loess Map, scale 1: 2,500,00. Quat Sci Rev 26:13011312

Hahm WJ, Riebe CS, Lukens CE, Araki S (2014) Bedrock composition regulates mountain ecosystems and landscape evolution. Proc Natl Acad Sci U S A 111:3338-3343

IUSS Working Group WRB (2015) World Reference Base for soil 721 resources 2014, update 2015 international soil classification 722 system for naming soils and creating legends for soil maps. World 723 soil resources reports no. 106. FAO, Rome

Jary Z (1996) Chronostratygrafia oraz warunki sedymentacji lessów południowo-zachodniej Polski na przykładzie Płaskowyżu Głubczyckiego i Wzgórz Trzebnickich. Studia Geograficzne LXIII Uniwersytetu Wrocławskiego, Wrocław
Jary Z (1999) Charakterystyka podstawowych horyzontów litologicznostrukturalnych lessach południowo-zachodniej 729 Polski. In: Jary Z (ed) III Seminarium Lessowe - Geneza i wiek pokrywowych utworów pylastych południowo-zachodniej Polski. Uniwersytet Wrocławski, Wrocław-Bożków Poland, pp 25-34

Jary Z (2007) Zapis zmian klimatu w górnoplejstoceńskich sekwencjach lessowo-glebowych w Polsce i w zachodniej części Ukrainy. Rozprawy Naukowe Instytutu Geografii i Rozwoju Regionalnego Uniwersytetu Wrocławskiego, Wrocław

Jary Z (2009) Periglacial markers within the Late Pleistocene loesspalaeosol sequences in Poland and Western Ukraine. Quat Int 198: 124-135

Jary Z, Ciszek D (2013) Late Pleistocene loess-palaeosol sequences in Poland and western Ukraine. Quat Int 296:37-50

Jenny H (1941) Factors of soil formation: a system of quantitative pedology. Dover, N

Kabala C, Bekier J, Bińczycki T, Bogacz A, Bojko O, Cuske M, ĆwielagPiasecka I et al (2015) Soils of Lower Silesia: Origins, diversity and protection. PTG, PTSH, Wrocław

Karathanasis AD, Macneal BR (1994) Evaluation of parent material uniformity criteria in loess-influenced soils of west-central Kentucky. Geoderma 64(1-2):73-92

Kowalska JB, Zaleski T, Józefowska A, Mazurek R (2019) Soil formation on calcium carbonate-rich parent material in the outer Carpathian Mountains - a case study. Catena 174:436-451

Kroyan SZ (2017) Changes of structural and aggregate composition of the mountain brown forest soils in the Republic of Armenia. Ann Agrar Sci 15:209-212

Kufmann C (2003) Soil types and eolian dust in high-mountainous karst of the Northern Calcareous Alps (Zugspitzplatt, Wetterstein Mountains, Germany). Catena 53:211-227

Lahtinen R (2000) Archaean - Proterozoic transition: geochemistry, provenance and tectonic setting of metasedimentary rocks in central Fennoscandian Shield, Finland. Precambrian Res 104:147-174

Lin Y, Feng J (2015) Aeolian dust contribution on the formation of alpine soils at Amado (Northen Tibetan Plareau). Geoderma 259-260:104 115

Linnemann U, Romer RL (2002) The Cadomian Orogeny in SaxoThuringia, Germany: geochemical and $\mathrm{Nd}-\mathrm{Sr}-\mathrm{Pb}$ isotopic characterization of marginal basins with constraints to geotectonic setting and provenance. Tectonophysics 352:33-64

Liu Y, Wu K, Wang X, Pei Y, Liu B, Guo J (2017) Fault zone of the Junggar Basin (NW China) with implications for the fault sealing process. J Asian Earth Sci 143:141-155

Markovic SB, Yang S, Mason J (2018) Editorial: Eurasian loess records. Palaeogeogr Palaeocl 509:1-3

Marks L, Gałązka D, Woronko B (2016) Climate, environment and stratigraphy of the last Pleistocene glacial stage in Poland. Quat Int 420: 259-271

Marks L, Makos M, Szymanek M, Woronko B, Dzierżek J, Majecka A (2019) Late Pleistocene climate of Poland in the mid-European context. Quat Int 504:24-39

Martignier L, Nussbaumer M, Adette T, Gobat JM, Verrecchia EP (2015) Assessment of locally-sourced loess system in Europe: the Swiss Jura Mountains. Aeolian Res 28:11-21

Mason JA, Jacobs PM, Gruley KE, Reyerson P, Hanson PR (2016) Parent material influence on soil response to vegetation change, Southeastern Minnesota, U.S.A. Geoderma 275:1-17

Mazurek R, Kowalska JB, Zadrożny P, Gąsiorek M, Kozak H (2018) Rendzinas diversity of the Ojców National Park as an effect of lithological factors. Soil Sci Annu 69(2):130-141

McLennan SM (2001) Relationships between the trace element composition of sedimentary rocks and upper continental crust. Geochem Geophys Geosyst 2:1-24 
Miszewski K (1977) Drobne struktury tektoniczne i następstwo deformacji w warstwach andelskohorskich (południowo-wschodnia częśĆ bloku przedsudeckiego). Geol Sudet 2(2):133-143

Muhs D (2013) The geologic records of dust in the Quaternary. Aeolian Res 9:3-48

Muhs DR, Benedict JB (2006) Eolian additions to late quaternary alpine soils, Indian Peaks Wilderness area, Colorado 826 front range. Arct Antarct Alp Res 38:120-130

Munroe JS, Farrugia G, Ryan PC (2007) Parent material and chemical weathering in alpine soils on Mt. Mansfield, 836 Vermont, USA. Catena $70: 39-48$

Munroe JS, Attwood EC, O'Keefe SS, Quackenbush PJM (2015) Eolian deposition in the alpine zone of the Uinta Mountains, Utah, USA. Catena 124:119-129

Neely EE, Barkworth ME (1984) Vegetation on soils derived from dolomite and quartzite in the Bear River Range, Utah: a comparative study. Bull Torrey Bot Club 111(2):179-192

Oberc J (1972) Tektonika cz.2. Sudety i obszary przyległe, Geolog, p. 307

Pasquini AI, Campodonico VA, Rouzaut S, Giampaoli V (2017) Geochemistry of a soil catena developed from loess deposits in a semiarid environment, Sierra Chica de Cordoba, central Argentina. Geoderma 295:53-68

Poręba GJ, Śnieszko Z, Moska P (2015) Application of OSL dating and ${ }^{137} \mathrm{Cs}$ measurments to reconstruct history of water erosion: a case study of Holocene colluvium in Świerklany, south Poland. Quat Int 374:189-197

Rodrigo-Comino J, Novara A, Gyasi-Agyei Y, Terol E, Cerda A (2018) Effects of parent material on soil erosion within Mediterranean new vineyard plantations. Eng Geol 246:255-261

Rousseau D-D, Sima A (2014) Abrupt climate changes recorded in loess sequences. Page Magazine 22(2):30-32

Romashkevich AI (1979) Ratio between the weathering and pedogenesis processes in mountain soils of Western Georgia. Pochvovedenie 4: 18-91 (in Russian)

Rudnick RL, Gao S (2003) Composition of the continental crust. Treatise Geochem 3:1-64

Rutherford GK, Sullivan DK (1970) Properties and geomorphic relationships of soils developed on a quartzite ridge near Kingston, Ontario. Can J Soil Sci 50(3):419-429

Sawicki L (1995) Detailed geological map of Sudetes Mountains. Sheet Głuchołazy -M33-71 Bb, 1:25 000

Schaetzl RJ, Luehmann MD (2013) Coarse-textured basal zones in thin loess deposits: products of sediment mixing and/or paleoenvironmental change? Geoderma 192:277-285

Schaetzl R, Bettis E, Crouvi O, Fitzsimmons K, Grimley D, Hambach U, Zech R (2018) Approaches and challenges to the study of loessintroduction to the LoessFest special issue. Quat Res 89(3):563-618

Scheib AJ, Birke M, Dinelli E, GEMAS Project Team (2014) Geochemical evidence of aeolian deposits in European soils. Boreas 43:175-192
Semmel A, Terhorst B (2010) The concept of periglacial cover beds in Central Europe: a review. Quat Int 222:120-128

Sitko M (1994) Góry Opawskie, Sudety, p. 205

Sprafke T, Thiel C, Terhorst B (2014) From micromorphology to palaeoenvironment: the MIS 10 to MIS 5 record in Paudorf (Lower Austria). Catena 117:60-72

Szlachta T (2006) Characteristics of the soil environment of the Opawskie Mountains Landscape Park, PhD thesis, Wrocław University of Environmental and Life Sciences (in Polish)

Ujvari G, Varga A, Balogh-Brunstad Z (2008) Origin, weathering and geochemical composition of loess in southwestern Hungary. Quat Res 69:421-437

Van Reeuwijk LP (2002) Procedures for soil analysis, 6th edn. ISRIC, Wageningen

Wang YS, Shi SL, Liu SY (1997) Soils in Qinghai Province. Chinese Agriculture Press, Beijing (in Chinese)

Waroszewski J, Kabala C, Sprafke T, Mysztyfaga E, Łabaz B, Woźniczka P (2018a) Aeolian silt contribution to soils on the mountain slopes silt origin slope covers and pedogenesis (Mt. Ślęża, SW Poland). Quat Res 89(3):702-717

Waroszewski J, Egli M, Brandova D, Christl M, Kabala C, Malkiewicz M, Kierczak J, Glina B, Jezierski P (2018b) Identifying slope processes over time and their imprint in soils of medium-high mountains of Central Europe (the Karkonosze Mountains, Poland). Earth Surf Process Landf 43:1195-1212

Waroszewski J, Sprafke T, Kabała C, Kobierski M, Kierczak J, Musztyfaga E, Loba A, Mazurek R, Łabaz B (2019) Tracking textural, mineralogical and geochemical signatures in soils developed from basalt-derived materials covered with loess sediments (SW Poland). Geoderma 337:983-997

Yaalon DH, Ganor E (1973) The influence of dust on soils during the quaternary. Soil Sci 116:146-155

Yamaguchi A, Ishikawa T, Kato Y, Nozaki T, Meneghini F, Rowe C, Moore J, Tsutsumi A, Kimura G (2014) Fluid-rock interaction recorded in black fault rocks in the Kodiak accretionary complex, Alaska. Earth Planets Space 66:58

Zádorová T, Penížek V (2018) Formation, morphology and classification of colluvial soils: a review. Eur J Soil Sci 69:755-591

Zarate M (2003) Loess of southern South America. Quat Sci Rev 22: 1987-2006

Zygmańska B (2016) Atlas Gór Polski, Wydawnictwo-SBM, pp 191

Zygmunt E (2009) Alluvial fans as an effect of long-term man-landscape interactions and moist climatic conditions: a case study from the Glubczyce Plateau, SW Poland. Geomorphology 108:58-70

Publisher's note Springer Nature remains neutral with regard to jurisdictional claims in published maps and institutional affiliations. 